\title{
The English Garden at Stan Hywet Hall and Gardens: Interpretation, Analysis, and Documentation of a Historic Garden Restoration
}

\author{
Mary C. Halbrooks
}

ADDITIONAL INDEX wORDs. historic landscape preservation, garden history, historic plants, landscape architecture, landscape design, cultural landscapes, Warren Manning, Ellen Biddle Shipman, Arts and Crafts style, women landscape architects, walled gardens

SumMary. Stan Hywet Hall and Gardens in Akron, Ohio, is a historical estate of national significance. Originally the home of the wealthy Seiberling family in the early 1900s, Stan Hywet Hall and Gardens was designed by renowned Boston landscape architect Warren Manning between 1911 and 1917. In 1915, the English Garden, one of several garden rooms on the estate, was designed by Manning as a walled, hidden garden. Thirteen years later, the garden's style was reconceived and its spatial dimensions restructured by Ellen Biddle Shipman, the foremost among women landscape architects of that time. Historic photographs document the implementation and maintenance of Shipman's design from 1928 to 1946. After 1946, the English Garden, lacking proper maintenance, was transformed into a shady retreat under towering evergreens on its perimeter. Few of the plantings from the Shipman period remained by 1989, whereas the architectural and structuring elements of the garden were still intact. The decision to restore the English Garden to Shipman's planting design provides a highly accurate representation of the garden during a particular period in its history (1928-46). Architectural rehabilitation of the garden's walls, walks, pathways, and pools was followed by an exacting restoration of the plantings according to Shipman's plans. In 1991, restoration of the English Garden was completed and it was opened to the public in 1992. Objectives of this paper are to 1) illustrate and illuminate contemporary historic landscape preservation practice and theory as applied to the English Garden at Stan Hywet Hall and Gardens and 2) document the horticultural methods associated with this historic garden restoration.

A cultural landscape is defined as "a geographic area, including both cultural and natural resources and the wildlife or domestic animals therein, associated with a historic event, activity, or person or exhibiting other cultural or aesthetic values." Like historic buildings or districts, cultural landscapes reveal aspects of a country's origins and development through their form and features and the ways they were used (Birnbaum, 1994). Today, "cultural landscape" serves as an umbrella term for different types of historic landscapes (Table 1). Historic landscapes may include residential gardens, community parks, scenic highways, rural communities, institutional grounds, cemeteries, battlefields, and zoological gardens. They may range in size from less than $\mathrm{l}$ acre ( $0.4 \mathrm{ha}$ ) to an area encompassing thousands of acres. All cultural landscapes are composed of a number of character-defining features that individually or collectively contribute to the landscapes' physical appearance as they have evolved over time (Birnbaum, 1994). Most historic properties have a cultural landscape component that is integral to the significance of the resource. A historic property consists of all its cultural resources-landscapes, buildings, archeological sites, and collections (Birnbaum, 1994). Historic landscape preservation is concerned with the protection and preservation of those cultural landscapes of historical significance. Historic designed landscapes such as gardens, arboreta, or estate grounds are a type of cultural landscape associated with horticultural practice (Table 1).

Department of Biological Sciences, Kent State University-Geauga, 14111 Claridon-Troy Rd., Burton, OH 44021.

Phone: 440-834-3731; fax: 440-834-8846; e-mail address: mhalbroo@kent.edu 
Table 1. Definitions of four general types of cultural landscapes and their associated examples.

\begin{tabular}{ll}
\hline Landscape type & \multicolumn{1}{c}{ Definition } \\
\hline Historic site & $\begin{array}{l}\text { A landscape significant for its association with a historic event, activity, or person. Examples include } \\
\text { battlefields and presidents' homes and properties. }\end{array}$ \\
Historic designed landscape & $\begin{array}{l}\text { A landscape significant as a design or work of art that was consciously designed or laid out by a } \\
\text { landscape architect, master gardener, architect, or horticulturist according to design principles, or } \\
\text { by an owner or other amateur according to a recognized style or tradition. The landscape may be } \\
\text { associated with a significant person(s), trend, or movement in landscape gardening or architecture; } \\
\text { or a significant relationship to the theory and practice of landscape architecture. Aesthetic values } \\
\text { play a significant role in designed landscapes. Examples include parks, campuses, estates, arboreta, } \\
\text { botanical and display grounds. } \\
\text { A landscape that evolved through use by the people whose activities or occupancy shaped that } \\
\text { landscape. Through social or cultural attitudes of an individual, family, or a community, the } \\
\text { landscape reflects the physical, biological, and cultural character of those everyday lives. Function } \\
\text { plays a significant role in vernacular landscapes. They can be a single property, such as a farm, or a } \\
\text { collection of properties, such as a district of historic farms along a river valley. Examples include } \\
\text { rural villages, industrial complexes, and agricultural landscapes. } \\
\text { A landscape containing a variety of natural and cultural resources that associated people define as } \\
\text { heritage resources. Examples are contemporary settlements, religious sacred sites, and massive } \\
\text { geological structures. Small plant communities, animals, subsistence and ceremonial grounds are } \\
\text { often components. }\end{array}$ \\
\hline Ethnographic landscape
\end{tabular}

${ }^{2}$ This term is sometimes considered synonymous with the term "rural historic landscape."

y This term is not commonly used in the National Register of Historic Places program.

Landscapes in need of preservation are dependent on natural resources in order to be sustained. The dynamic qualities of the biotic and abiotic components of such landscapes (air, water, vegetation, wildlife) differentiate cultural landscapes from other cultural resources, such as historic structures. It is for this reason that the documentation, treatment, and ongoing management of these landscapes require a comprehensive, multidisciplinary approach. A broad array of academic backgrounds, training, and related project experience is needed for preservation planning and management of cultural landscapes. Professionals may have expertise in landscape architecture, history, landscape archaeology, forestry, agriculture, horticulture, pomology, pollen analysis, planning, architecture, engineering, cultural geography, wildlife, ecology, ethnography, interpretation, material and object conservation, landscape maintenance, and management (Birnbaum, 1994).

Since the late 1970s and early 1980s, the field of historic landscape preservation has become an increasingly well-defined and interconnected community of scholars, professionals and practicing preservationists from a wide range of disciplinary backgrounds including horticulture (Birnbaum and Barrett, 2000). While scholarly publications and project work in historic landscape preservation have expanded rapidly over these past 30 years, little, if any, of this literature has been published within mainstream horticultural science. Publications are needed that introduce the current knowledge in historic landscape preservation to a wider horticultural audience. Published models of historic landscapes and related preservation processes are also needed to begin to build a base of scientific literature in historic landscape preservation that is widely available to horticulturists.

Stan Hywet Hall and Gardens in Akron, Ohio, is one example of a cultural landscape. Originally the home of the Seiberling family from 1917 to 1955, Stan Hywet Hall and Gardens now operates as a museum open to the public and is listed on the National Register of Historic Places (Historic American Buildings Survey, 2003). Since 1957, Stan Hywet Hall and Gardens has been managed by a private, not-for-profit corporation, the Stan Hywet Hall and Gardens Hall Foundation, for the purpose of preserving, maintaining, and operating the property as a cultural and educational center for public benefit and to preserve the original artistic character of the estate.

\section{Historical background}

In 1911, F.A. Seiberling, founder of the Goodyear Tire and Rubber Company, and his wife, Gertrude, commissioned Warren Manning to design the landscape of their new estate. Manning, a landscape architect, and Charles Schneider, the architect responsible for the design of the Tudor-style manor house at Stan Hywet Hall and Gardens, collaborated on many aspects of the overall design for the estate. Manning worked closely with Schneider to extend the interior living spaces into the gardens and the countryside beyond by creating outdoor rooms and paths that lead to seven vistas (McCormick, 1994). Warren Manning's distinguished career as a leading landscape architect of the early 20th century and the enduring historic significance of Stan Hywet Hall and Gardens are well documented (Griswold and Weller, 1991; Levinson, 1991; Linden-Ward, 1987; McCormick, 1994; Neckar, 1989). During the 1970s and 1980s a complete restoration of the manor house and grounds was initiated and has continued to the present. Stan Hywet Hall and Gardens is perhaps the most complete extant design by Warren Manning and his best surviving work for a private client (Griswold and Weller, 1991; W. Kendall-Hess, unpublished). Stan Hywet Hall and Gardens is also very significant in American garden history as one of the great estate gardens of the period of time, 1890 to 1940 , known as the American Country Place Era (Griswold and Weller, 1991; Rogers, 2001). 
The English Garden at Stan Hywet Hall and Gardens is one of several garden rooms of the estate and is an example of the Arts and Crafts aesthetic of this period (Linden-Ward, 1987; Tankard, 1996). Originally designed in 1915 by Warren Manning, the English Garden was a hidden, walled garden. According to family history, Gertrude Seiberling wanted a private garden, unnoticeable from the house or nearby gardens. The garden became a favorite retreat for Gertrude and her family over the years that they lived on the estate. The history of the English Garden is significant principally due to the role of the renowned landscape architect, Ellen Biddle Shipman, in its redesign in 1928 (Tankard, 1996). After a long period of neglect between 1946 and 1989, the English Garden underwent restoration between 1989 and 1991 and was reopened to the public in 1992. Preservation planners G. Doell and C. Doell, garden historians and landscape preservation planners of Syracuse, N.Y., were commissioned by the Stan Hywet Hall and Gardens Board of Trustees to oversee the restoration process of the English Garden. A comprehensive study of the English Garden led to formulation of 1) preservation goals and policies for the English Garden, referred to as a preservation concept; and 2) management strategies for the restoration project, referred to as a restoration process plan (G. Doell and C. Doell, unpublished report). The restoration of the English Garden provides an excellent model of preservation practices and the associated horticul- tural methods applied to restoration processes of historic landscapes.

\section{Preservation planning}

Preserving historic designed and vernacular landscapes requires a stepby-step process known as preservation treatment. Guidelines that provide a framework for the process of preservation treatment have been developed by the U.S. Secretary of the Interior and should be followed when developing a preservation treatment plan (Birnbaum and Peters, 1996). These guidelines are useful for management of all cultural landscapes and have been widely adopted by preservation professionals in private practice, cultural resource managers, and historic property owners (Birnbaum, 1994). Four primary treatments are identified in the guidelines: preservation, rehabilitation, restoration, and reconstruction (Table 2). Birnbaum and Peters (1996) explain how to apply these four treatments to cultural landscapes in a way that meets those standards. Careful planning prior to undertaking work can help prevent irrevocable damage to a cultural landscape. Adopting comprehensive treatment and management plans, in concert with a preservation maintenance strategy, acknowledges a cultural landscape's ever-changing nature and the interrelationship of treatment, management and maintenance (Birnbaum, 1994).

Generally, the preservation process involves the following steps: historical research; inventory and documentation of existing conditions; site analysis and evaluation of integrity and significance; development of a cultural landscape management plan and management philosophy; development of a strategy for ongoing maintenance; and preparation of a record of treatment and future research recommendations (Birnbaum, 1994). The steps in this process are not independent of each other, nor are they always sequential. Information gathered in one step may lead to a reexamination or refinement of previous steps. The overall management philosophy or stated goals of a historic property may necessitate additional studies, such as management plans, interpretive plans, exhibit design, or a historic structures report (Birnbaum, 1994).

The processes undertaken to develop a treatment approach and recommendations for the horticultural restoration were, in this order, 1) historical research; 2 ) inventory and documentation of existing conditions; 3 ) site analysis and evaluation of integrity and significance; and 4) development of a landscape preservation approach and treatment plan (G. Doell and C. Doell, unpublished report). A discussion of the step-by-step process of the English Garden's restoration illustrates the decision-making and data collection processes involved in preservation planning and treatment.

\section{Preservation methodology}

\section{Historical research}

Historic research conducted by G. Doell and C. Doell concentrated

Table 2. Primary treatment types for cultural landscapes are identified in the Secretary of the Interior's Standards for the Treatment of Historic Properties (Birnbaum and Peters, 1996).

\begin{tabular}{ll}
\hline Treatment type & \multicolumn{1}{c}{ Description } \\
\hline Preservation & $\begin{array}{l}\text { The act or process of applying measures necessary to sustain the existing form, integrity, and materials of a } \\
\text { historic property. Work, including preliminary measures to protect and stabilize the property, generally focuses } \\
\text { upon the ongoing maintenance and repair of historic materials and features }{ }^{z} \text { rather than extensive replacement } \\
\text { and new construction. New additions are not within the scope of this treatment; however, the limited and } \\
\text { sensitive upgrading of mechanical, electrical, and plumbing systems and other code-required work to make } \\
\text { properties functional are appropriate within a preservation project. }\end{array}$ \\
& $\begin{array}{l}\text { The act or process of making possible a compatible use for a property through repair, alterations, and } \\
\text { additions while preserving those portions or features that convey its historical or cultural values. }\end{array}$ \\
Rehabilitation & $\begin{array}{l}\text { The act or process of accurately depicting the form, features, and character of a property as it appeared at a } \\
\text { particular period of time by means of the removal of features from other periods in its history and }\end{array}$ \\
Restoration & $\begin{array}{l}\text { reconstruction of missing features from the restoration period. The limited and sensitive upgrading of } \\
\text { mechanical, electrical, and plumbing systems and other code-required work to make properties functional } \\
\text { are appropriate within a restoration project. } \\
\text { The act or process of depicting, by means of new construction, the form, features, and detailing of a } \\
\text { nonsurviving site, landscape, building, structure, or object for the purpose of replicating its appearance at a } \\
\text { specific period of time and in its historic location. }\end{array}$ \\
Reconstruction &
\end{tabular}


Table 3. A chronology of the English Garden at Stan Hywet Hall and Gardens, Akron, Ohio. Time periods are delineated by major events in the garden's history: 1915, Manning's design for the English Garden is completed; 1928, Shipman redesigns the garden in new color theme at the request of G. Seiberling; 1946, G. Seiberling dies; and 1989, rehabilitation of the garden's architecture and restoration of garden plantings are initiated. Three significant persons are associated with the garden's design and each person's artistic contributions are shown during the period(s) in which the major elements of that contribution were implemented, preserved, or changed.

\begin{tabular}{|c|c|c|c|}
\hline \multirow[b]{2}{*}{ Designer } & \multicolumn{3}{|c|}{ Artistic contribution } \\
\hline & $1915-28$ & $1928-46$ & 1946-89 \\
\hline \multirow[t]{3}{*}{$\begin{array}{l}\text { Warren H. } \\
\text { Manning }\end{array}$} & $\begin{array}{l}\text { Garden style }^{z} \text { and major } \\
\text { architectural features }{ }^{y} \text { established }\end{array}$ & $\begin{array}{l}\text { Garden style and major architectural } \\
\text { features still present }\end{array}$ & $\begin{array}{l}\text { Garden style and major architectural } \\
\text { features recently rehabilitated }{ }^{t}\end{array}$ \\
\hline & $\begin{array}{l}\text { Perennials and vines on list }{ }^{\mathrm{x}} \\
\text { established in the garden }\end{array}$ & $\begin{array}{l}\text { Most plants on Manning's list } \\
\text { removed when Shipman planting } \\
\text { plan is implemented }\end{array}$ & $\begin{array}{l}\text { Five plants survive that Shipman } \\
\text { retained }^{s}\end{array}$ \\
\hline & $\begin{array}{l}\text { Trees and shrubs planted on } \\
\text { outer perimeter of garden walls as } \\
\text { a screen to hide garden from view }\end{array}$ & $\begin{array}{l}\text { Some trees removed per Manning's } \\
\text { instruction; most remain in place }\end{array}$ & $\begin{array}{l}\text { Trees on outer perimeter reach heights } \\
\text { of greater than } 80 \mathrm{ft}(24.4 \mathrm{~m}) \text {; lower } \\
\text { branches lost and wall is now visible }\end{array}$ \\
\hline $\begin{array}{l}\text { Willard D. } \\
\text { Paddock }\end{array}$ & $\begin{array}{l}\text { "Garden of the Water Goddess"w } \\
\text { as focal point of the garden, } \\
\text { situated north of reflecting pool }\end{array}$ & $\begin{array}{l}\text { Statue is retained by Shipman as focal } \\
\text { point of garden; statue becomes } \\
\text { discolored and damaged }\end{array}$ & Statue rehabilitated ${ }^{t}$ \\
\hline $\begin{array}{l}\text { Ellen B. } \\
\text { Shipman }\end{array}$ & ---- & $\begin{array}{l}\text { Garden's planting plan changed by } \\
\text { new specifications and placement of } \\
\text { perennials, and trees; spatial/visual } \\
\text { organization reconfigured; few of } \\
\text { Manning's plants retained }\end{array}$ & $\begin{array}{l}\text { Shipman planting plan deteriorates; } \\
\text { gradually transformed by replacement } \\
\text { of Shipman-specified plants with shade- } \\
\text { tolerant plants; visual and spatial } \\
\text { properties lost }\end{array}$ \\
\hline
\end{tabular}

${ }^{2}$ Arts and Crafts style.

${ }^{y}$ Feature is defined as the smallest element of a landscape that contributes to the significance of the landscape.

${ }^{x}$ Manning prepared a list of plants for the garden but did not specify placement.

"Name attributed to the bronze fountain/statue group.

"Shipman prepared a perennial planting plan and a shrub planting plan.

uShipman retained Manning's climbing roses, tree peonies, espaliered pear trees, one white oak, and one black tupelo.

'Architectural rehabilitation of garden structures and Paddock statue completed in 1989-90.

sThree tree peonies, one white oak, one black tupelo.

on understanding the design intent of the landscape architects, Warren Manning and Ellen Biddle Shipman and the changes that took place in the garden between 1946 and 1989 (Table $3)$. Primary resources used in research included archival documents such as Shipman's original plans, period correspondence between the Seiberlings and the principal designers, plant lists, historic photographs and background material on Manning, Shipman, and the Seiberlings.

Design InTent, 1915-28. The English Garden was part of Manning's original master plan for the Stan Hywet Hall and Gardens estate. Designed to be secluded, the garden's enclosing stone walls were intentionally hidden by densely planted evergreen, coniferous trees planted outside the garden's stone walls. Notes from Manning's office indicate that the evergreen trees were faced down with deciduous shrubs to fill in any gaps left between the lower portions of the evergreens. Within the garden, Manning proposed a perennial garden including annuals, biennials, perennials, bulbs and vines.
Manning did not prepare any planting plans for the English Garden so there is no historic record of the arrangement of these plants within the garden. Archival photographs (Fig. 1) taken within the English Garden between 1919 and 1928 document Manning's design concept for the English Garden as a flower garden and its architectural organization including the formal, cross-axial design; the interior walls accented by trellises; a reflecting pool and the focal point of the garden, a sculpture/fountain entitled "Garden of the Water Goddess" created by American sculptor Willard Dryden Paddock.

Design INTENT, 1928-46. In 1928, the Seiberlings commissioned Ellen Biddle Shipman to redesign the English Garden. Two planting plans, entitled "A Shrub Planting Plan for the Garden of Mrs. F.A. Seiberling" and "A Perennial Planting Plan for the Garden of Mrs. F.A. Seiberling," were prepared in 1929 and are surviving archival documents. Shipman's plans are elaborate designs with perennials arranged in fan-shaped groupings and shrubs placed at strategic places within the garden to create strong visual interest (Fig. 2). Shipman specified 112 species of perennials and vines in various shades of blue, white, pink and yellow, a color scheme requested by Gertrude Seiberling. An important feature of Shipman's plan for the garden is that she retained some of the plants original to Manning's design including climbing roses (Rosa species and hybrids), tree peonies (Paeonia suffruticosa), and espaliered pear trees (Pyrus spp.) (Fig. 3). Historic photographs taken in the late 1930s and early 1940s show that several woody shrubs and trees as specified on Shipman's shrub planting plan had been planted (Fig. 4). Although no photographs were found that show all of the perennials specified in the Shipman plan, it was "likely that the perennial plan was implemented as well", according to G. Doell and C. Doell. By 1942 lilies (Lilium spp.) were no longer present among the japanese yew (Taxus cuspidata) shrubs as specified by Shipman. Additionally, the yew shrubs were now sheared tightly, rather than loosely, as 


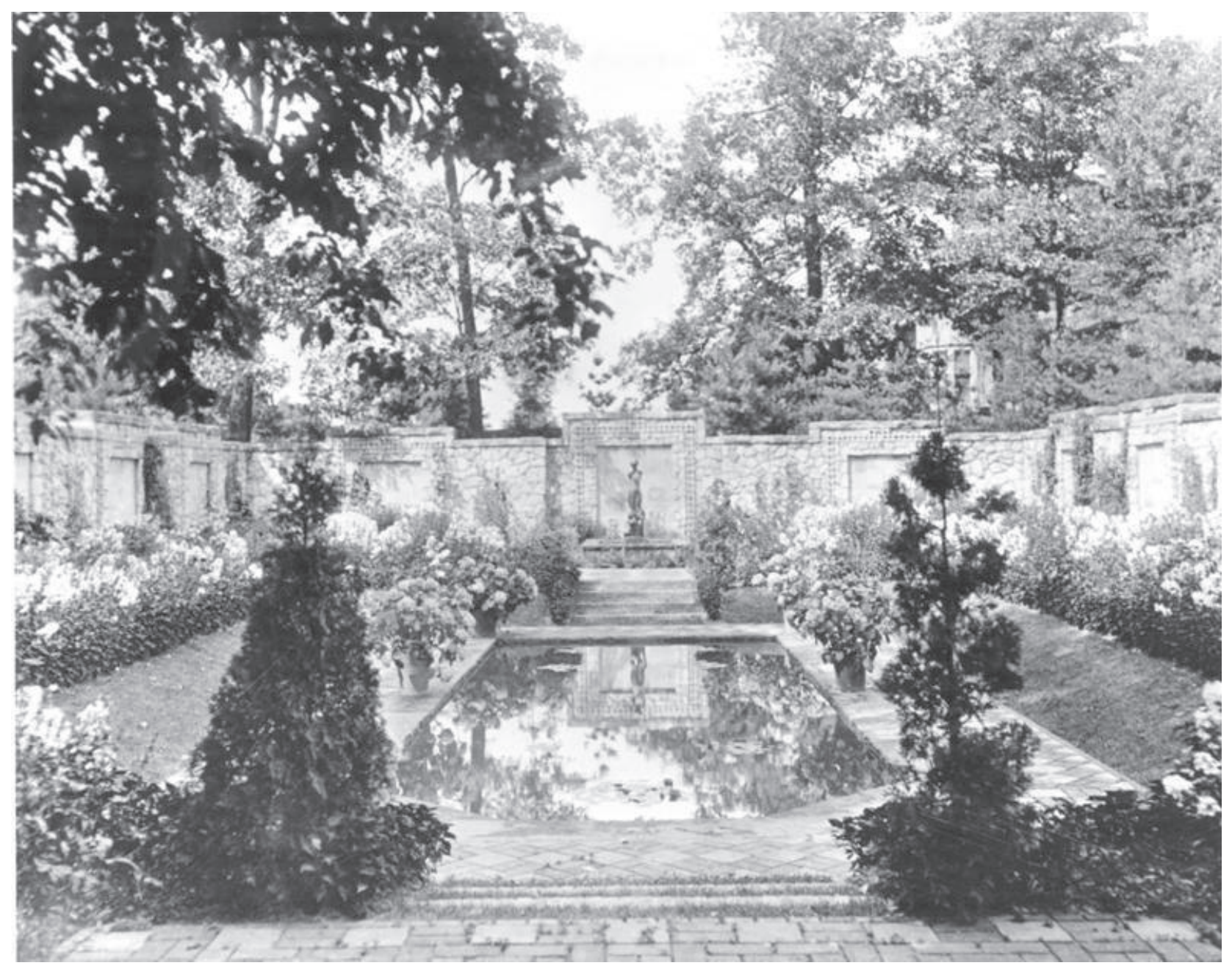

Fig. 1. This historic photograph documents the appearance of the English Garden at Stan Hywet Hall and Gardens in Akron, Ohio, circa 1920, with a view into the garden looking north. Stan Hywet Hall and Gardens was the home of the Seiberling family from 1917 until 1955 when it was incorporated as a nonprofit museum open to the public. The English Garden is one of several garden rooms on the estate designed by Warren Manning, landscape architect, in collaboration with architect Charles Schneider. Manning's 1917 design concept for the English Garden was a walled, hidden flower garden in the Arts and Crafts style. The garden's layout is a formal, cross-axial design with brick walkways and pools. Interior walls, made of hand-hewn native stone, are accented by trellises designed to support climbing roses. North of the reflecting pool is the primary focal point of the garden, a sculpture/fountain entitled "Garden of the Water Goddess," created by American sculptor Willard Dryden Paddock. Surrounding the garden walls, on the outer perimeter, are evergreen trees planted as a screen to block any view of the "hidden" garden. (CStan Hywet Hall and Gardens, Akron, Ohio)

Shipman intended (Fig. 4) (G. Doell and C. Doell, unpublished report).

Post-Design Changes, 194689. By the mid-1940s, the English Garden began to deteriorate. G. Doell and C. Doell cited several archival photographs as evidence of the garden's untidy appearance and several woody species, seen in earlier photographs, had disappeared. By 1955, the Akron Garden Club was maintaining the garden. Gradually, light conditions within the garden worsened due to the increased height of the evergreen trees on the outer perimeter of the garden wall. As plants within the garden died out, they were replaced with more shade-tolerant plants not specified in the Shipman plan (Fig. 5 ). The garden's transformation over the years was summarized by the preservation planners, G. Doell and C. Doell, who stated in their report: "Eventually, the English Garden no longer resembled the flower garden that Gertrude Seiberling and her family knew."

\section{Inventory and documentation of existing conditions}

In addition to historic research, physical evidence of the landscape as it exists in the present is needed to guide the historic preservation plan and treatments (Birnbaum, 1994). Landscape documentation and inventory provide a detailed record of the landscape and its features as a baseline for future reference. For the English Garden, existing conditions were documented (prior to restoration) by 1) verifying the location of the garden's structural elements (structures, circulation systems, garden ornaments, site furnishings, plant materials and utilities) on a topographic survey; 2) recording the location, size, condition and identity of all trees, shrubs, and herbaceous plants in and surrounding the English Garden; and 3) recording and evaluating light conditions within 


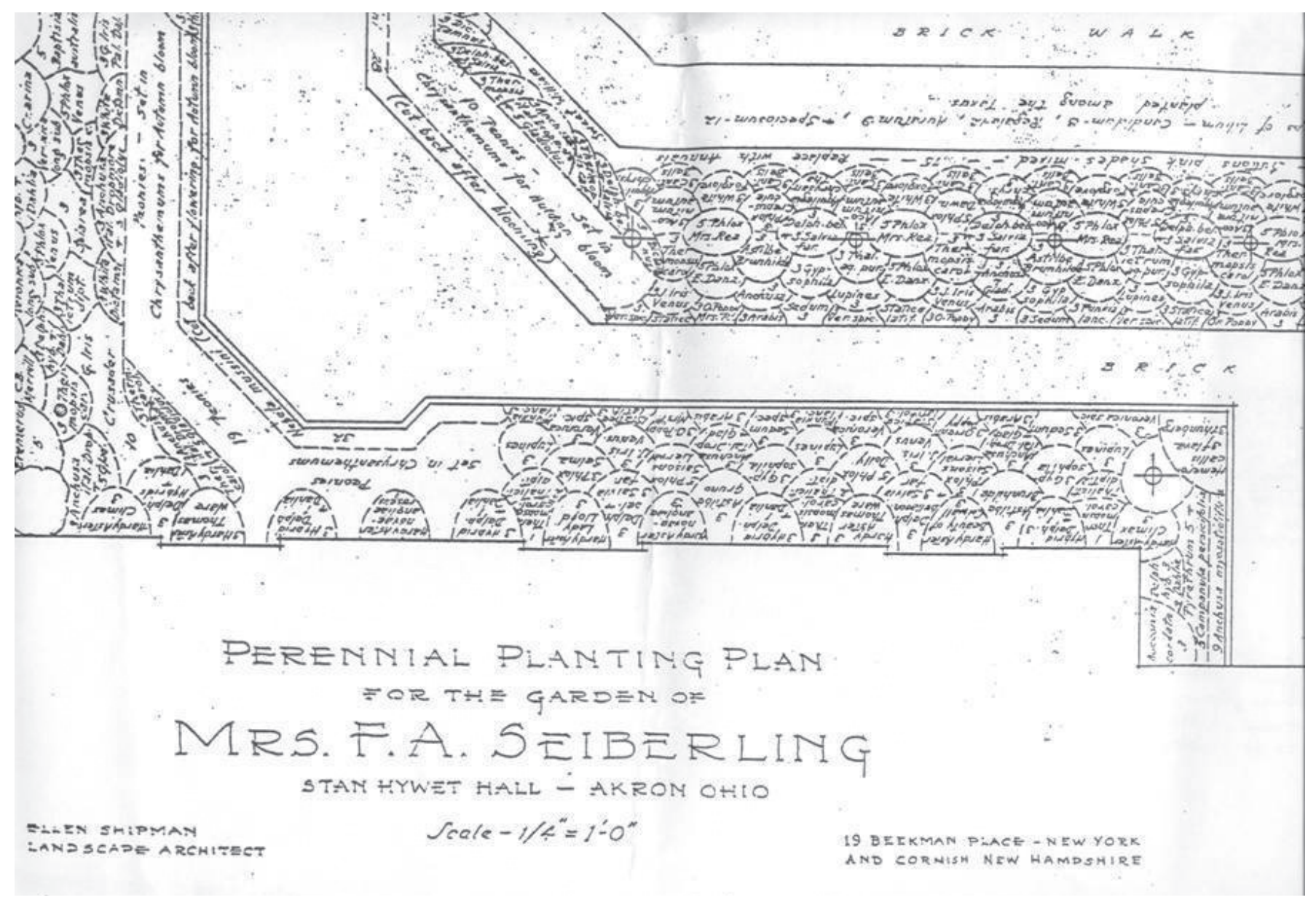

Fig. 2. This section of a garden plan entitled "Perennial Planting Plan for the Garden of Mrs. F.A. Seiberling" was prepared in 1929 by the office of Ellen Biddle Shipman, landscape architect, for the English Garden at Stan Hywet Hall and Gardens, Akron, Ohio. In 1928, the Seiberlings commissioned Shipman to redesign the English Garden. Two planting plans, entitled "A Shrub Planting Plan for the Garden of Mrs. F.A. Seiberling" and "A Perennial Planting Plan for the Garden of Mrs. F.A. Seiberling," were prepared in 1929 and are surviving archival documents. Shipman's plans are elaborate designs with perennials arranged in fan-shaped groupings. See Fig. 1 caption for additional background information. (@Stan Hywet Hall and Gardens, Akron, Ohio)

the garden (G. Doell and C. Doell, unpublished report).

Structuring elements. The English Garden is located on the west side of the Seiberling manor home, immediately south of the West Terrace (Fig. 6). The garden is longer on its north to south axis, measures $60 \times 120$ $\mathrm{ft}(18.3 \times 36.6 \mathrm{~m})$ and is completely enclosed by 8 -ft $(2.4 \mathrm{~m})$ stone walls. Walls on the west and south sides are free-standing, whereas walls on the east and north retain up to $6 \mathrm{ft}(1.8 \mathrm{~m})$ of soil, creating the effect of a sunken garden. Major architectural elements of the garden include the walls, walkways, entrances, pools, and statues (Figs. 7 and 8).

Plant materials inventory. In 1990, 45 woody plant and herbaceous ground cover species within the garden were in good condition. Since most were competing for sunlight, however, their growth habit was etiolated and/or contorted. Outside the garden walls was a mixed planting of evergreen and deciduous trees with an understory of deciduous and broadleaf evergreen shrubs. Among the trees surrounding the garden $65 \%$ were in good condition, $29 \%$ in fair condition, and $6 \%$ in poor condition. The evergreen trees, white pine (Pinus strobus), canadian hemlock (Tsuga canadensis), norway spruce (Picea abies), and deciduous trees [tuliptree (Liriodendron tulipifera) and oak (Quercus spp.)] ranged in height from $35-80 \mathrm{ft}(10.7-24.4 \mathrm{~m})$ and $80-100 \mathrm{ft}(24.4-30.5 \mathrm{~m})$, respectively. Most of the evergreen trees were overly mature with height to branching above $6-8 \mathrm{ft}(1.8-2.4 \mathrm{~m})$ creating open spaces in the perimeter planting and failing to block views of the wall.
Understory shrubs of several genera included deutzia (Dentzia), sweet mockorange (Philadelphus), viburnum (Viburnum), spicebush (Lindera), rhododendron (Rhododendron), and mountain laurel (Kalmia), among which $60 \%$ were in good condition and $40 \%$ in fair condition. Shrubs ranged in height from 6-12 ft (1.8-3.7 m).

Light conditions. Existing light conditions were measured using a standard photographic light meter and illuminance was recorded in footcandles. Light readings were taken at 16 locations throughout the interior of the garden (eight on the perimeter paths and eight along the walkway surrounding the reflecting pool) $4 x$ daily $(0900,1200,1500$, and 1800 $\mathrm{HR}$ ) on each of three consecutive days (26-28 June 1990). Sky conditions varied from clear to overcast to cloudy 


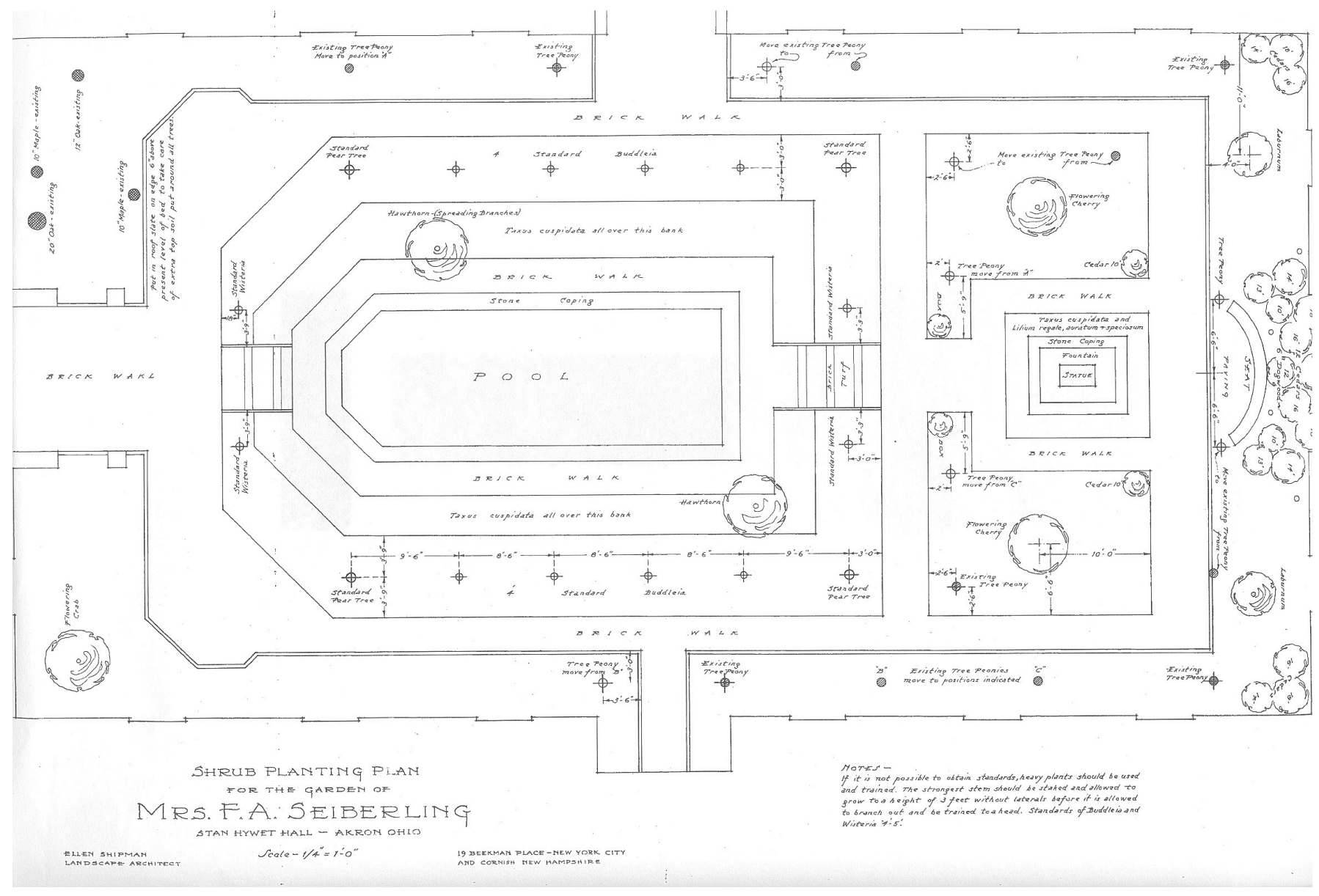

Fig. 3. This garden plan, entitled "Shrub Planting Plan for the Garden of Mrs. F.A. Seiberling," is Ellen Biddle Shipman's original 1929 plan for the redesign of the English Garden at Stan Hywet Hall and Gardens in Akron, Ohio. This representation of the garden is oriented with the main garden entrance (south) on the left. In 1928, the Seiberlings commissioned Ellen Biddle Shipman, landscape architect, to redesign the English Garden. The shrub planting plan includes some woody plants Shipman chose to retain from Manning's earlier design including climbing roses (Rosa spp. and hybrids) and espaliered pear trees (Pyrus spp.) along the inside walls (not shown here), and tree peonies (Paeonia suffruticosa) that were relocated from Manning's original placement. Shipman's placement of shrubs and trees at strategic points within the garden created strong visual interest, such as sargent cherry trees (Prunus sargentii), and pear tree and butterfly-bush (Buddleia davidii) standards. The border of japanese yew shrubs (Taxus cuspidata) surrounding the reflecting pool dramatized the three-dimensional quality of the garden, while the grouping of eastern arborvitae trees (Thuja occidentalis) behind the fountain intentionally highlighted the sculptural group as the main focal point of the garden. See Fig. 1 caption for additional background information. (@Stan Hywet Hall and Gardens, Akron, Ohio)

over the 3 -d period. As a control, light readings were also made at two other open areas on the estate, known as the Great Meadow (area with no trees) and the West Terrace (a few trees on the east side near the house) (Fig. 9). Illuminance levels were greater in the Great Meadow and the West Terrace by 4 and $3.2 \times$, respectively, compared to illuminance levels within the English Garden (Fig. 10). (In contrast, the English Garden is surrounded by tall evergreen and deciduous trees on the outer perimeter of the garden.) Within the English Garden average illuminance near the pool was greater by $2 \times$ compared to illuminance levels along the perimeter paths (Fig. 10).
The brightest areas near the pool were on the north and west; whereas the brightest areas on the perimeter paths were on the south and east.

\section{Site analysis: Evaluation of integrity and significance}

Assessment of the cultural and historic value of a landscape can be achieved by analyzing the landscape as a continuum through time. By documenting the landscape at different periods of its history, individual features can be attributed to a particular period when they were introduced and the various periods when they were present, thus establishing the significance and integrity of a landscape. Significance re- fers to the meaning or value ascribed to a cultural landscape; whereas integrity is a measure of a landscape's authenticity as evidenced by the survival of the physical characteristics that existed during the property's historic period (Birnbaum, 1994). Evaluations of significance and integrity are essential to the process of developing treatment plans. G. Doell and C. Doell analyzed the chronological and physical layers of the English Garden, as established by historical research and the Existing Conditions report (prepared by Child, Hornbeck Associates, Cambridge, Mass.), in developing their assessment of the significance and integrity of the English Garden. 
Figs. 4-5. These historic photographs document the appearance of the English Garden at Stan Hywet Hall and Gardens in Akron, Ohio, circa 1942 (top) and 1969 (bottom), with a view into the garden looking north. The English Garden is one of several garden rooms on the estate designed by Warren Manning, landscape architect, in collaboration with architect Charles Schneider. Manning's 1917 design concept for the English Garden was a walled, hidden flower garden in the Arts and Crafts style. In 1928, the Seiberlings commissioned Ellen Biddle Shipman, landscape architect, to redesign the English Garden. Shipman's design was implemented some time after 1929 and was maintained to a high standard until the 1940s. (OStan Hywet Hall and Gardens, Akron, Ohio)

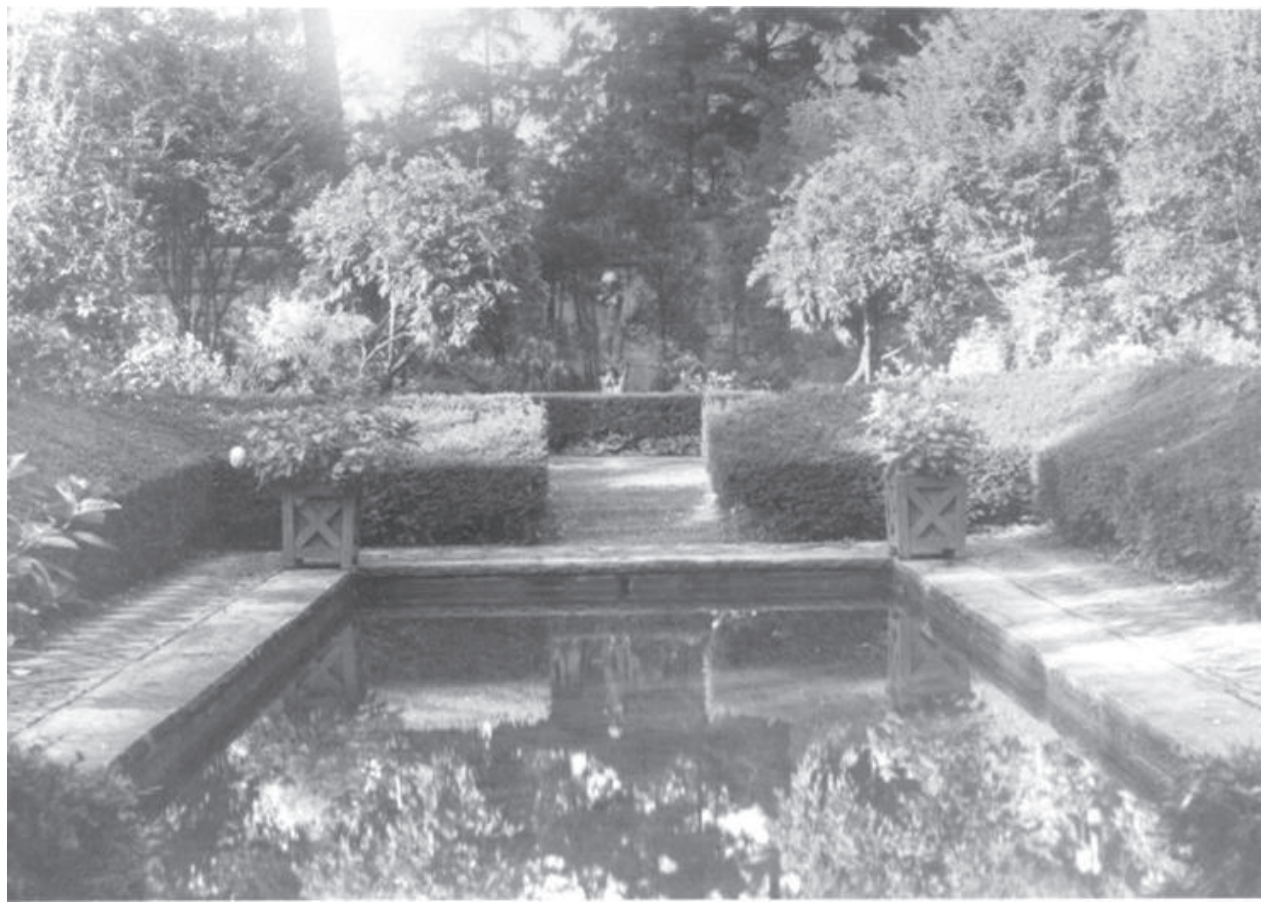

Fig. 4 (above). Some of the notable Shipman features are wisteria (Wisteria sinensis) standards, a border of japanese yew shrubs (Taxus cuspidata) around the reflecting pool and eastern arborvitae (Thuja occidentalis) behind the sculpture/fountain group, "The Garden of the Water Goddess," by Willard Dryden Paddock. The perennial flowers Shipman incorporated into her design are not visible in this photograph. The tight shearing of the yew shrubs and absence of lilies (Lilium) among the shrubs are notable changes from earlier years of the Shipman design.

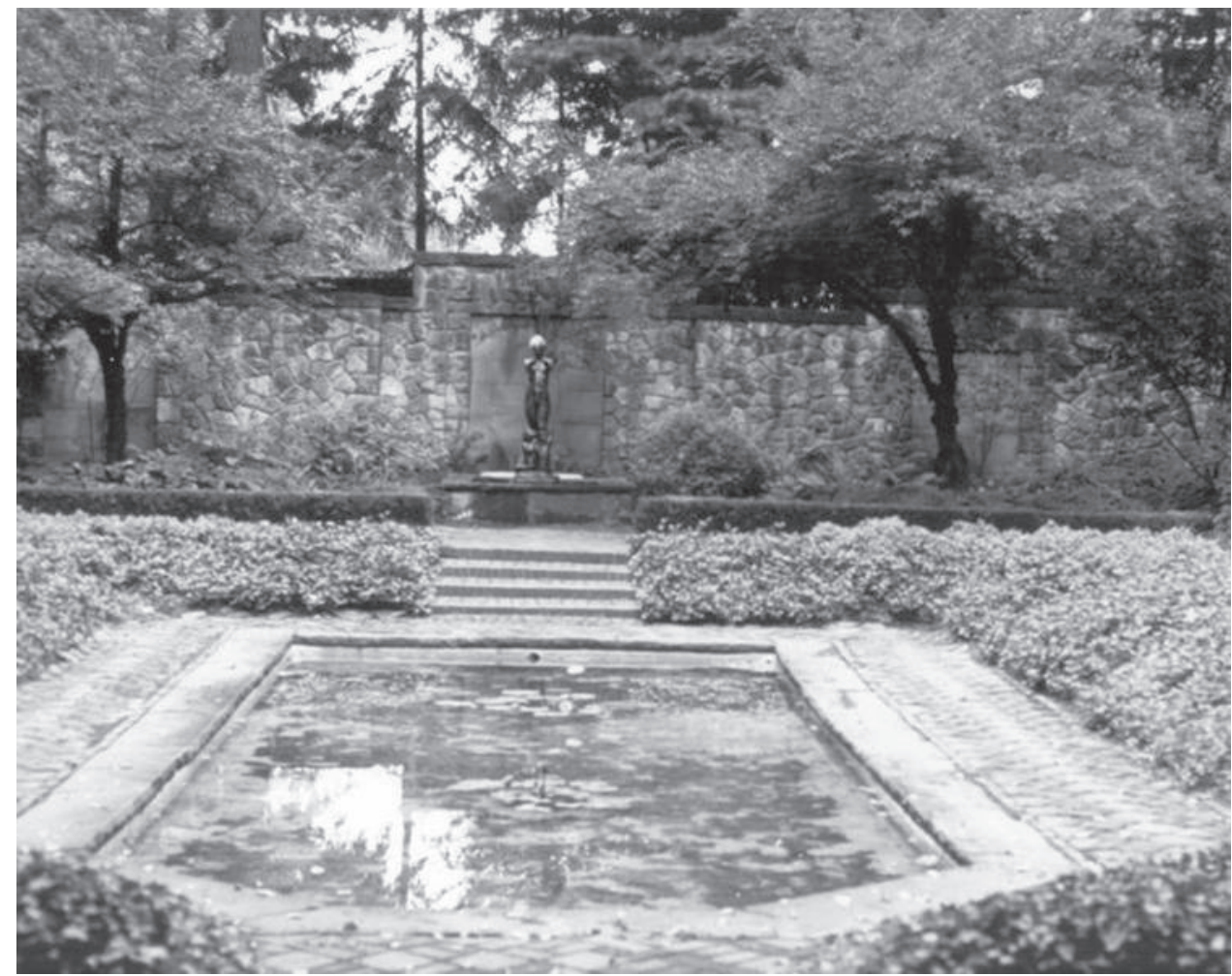

Fig. 5. By 1969, nearly all of the perennial plants specified in Shipman's planting plans for the redesign had died out and been replaced by more shade-tolerant plants. Many of the shrubs and trees specified by Shipman had also been lost or removed with the exception of two sargent cherry (Prunus sargentii) trees, visible here on both sides of the fountain/statue group. Shade cast into the garden's interior by the towering evergreen trees on the outer perimeter of the garden walls contributed to the loss of the sun-loving perennials in Shipman's design. 


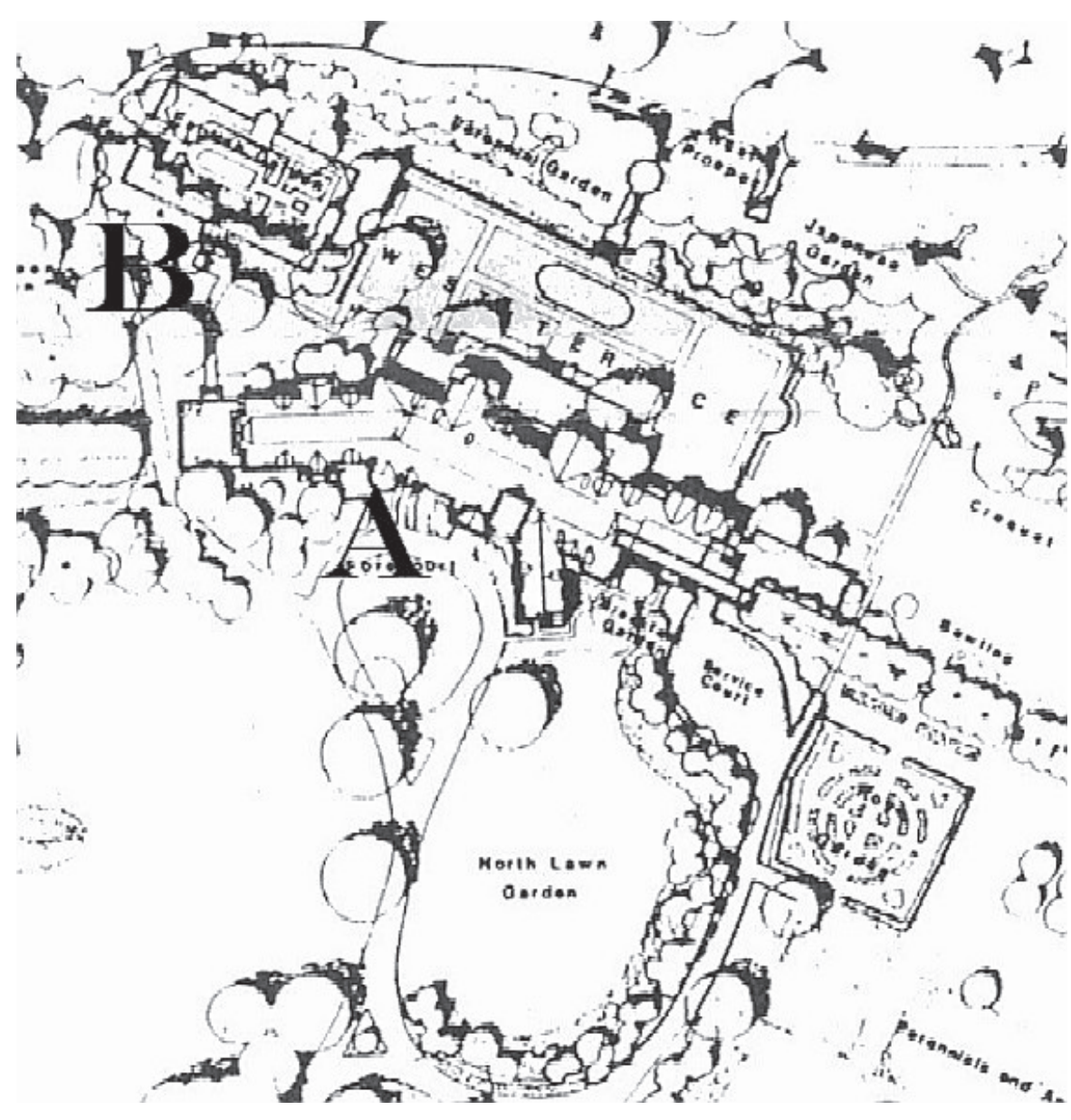

Significance of the EngLish Garden. Three significant persons were clearly associated with the design of the English Garden (Table 3). As early as 1915, Warren Manning established the garden's fundamental style, scale, materials, design and layout and integrated it into the larger design for the Seiberling estate. At the same time, Willard Paddock created the sculptural group "Garden of the Water Goddess," providing the garden with its primary focal point. Thirteen years later, Ellen Shipman revised the garden's composition by creating new planting plans and fundamentally changing the visual/spatial properties, color scheme, massing, texture and succession of bloom. Shipman's plan retained a few of Manning's original plants and all of the garden's architectural and structural elements including Paddock's sculptural group. Based on these findings, G. Doell and C. Doell recommended the period of significance be established as 1929-46, which begins with Shipman's design and ends with the death of Mrs. Seiberling. This historic period is better documented than any other in the garden's history by 1) Shipman's planting plans with plant lists, and 2) historic photographs that reveal Shipman's plantings and Manning's design elements in place simultaneously.

INTEgRITY OF THE ENGLISH GARDEN. The aspect of the English Garden exhibiting the highest degree of historical integrity was its physical structure. The fundamental layout of the garden as conceived by Manning-its enclosing stone walls, brick walkways, wrought iron hardware, reflecting pool, electrical and circulation systems-had all survived until 1989. These structural elements and the sculptural group "The Garden of the Water Goddess" by Paddock had needed only rehabilitation to return them to good condition. A high degree of integrity was also associated with the plantings outside the garden walls. The deciduous trees, which predate the garden's construction, evergreen trees and woody shrubs were still alive. Their design intent, as a screen to hide the garden from view, had been lost as the trees grew taller and lost lower branches. An additional problem was that the trees were shading the garden's

Fig. 6. This section of a site plan of Stan Hywet Hall and Gardens, Akron, Ohio, was originally a part of the Existing Conditions Report prepared by Child, Hornbeck Associates in 1984 as part of the restoration planning for the entire estate. The English Garden (just above "B") is in close proximity to the Seiberling manor house (just above "A"). Stan Hywet Hall and Gardens was the home of the Seiberling family from 1917 until 1955 when it was incorporated as a nonprofit museum open to the public. The English Garden is one of several garden rooms on the estate designed by Warren Manning, landscape architect, in collaboration with architect Charles Schneider. Manning's 1917 design concept for the English Garden was a walled, hidden flower garden in the Arts and Crafts style. In 1928, the Seiberlings commissioned Ellen Biddle Shipman, landscape architect, to redesign the English Garden. Other parts of the estate shown here are the many smaller garden rooms. (CStan Hywet Hall and Gardens, Akron, Ohio)

interior much more than when they were planted in 1915. In contrast, plantings within the garden had the lowest degree of integrity. This was attributed to the incremental replacement of nearly all of the plants specified by Shipman-trees, shrubs and perennials-by more shade-tolerant woody plants and herbaceous ground covers. Among the 45 woody plant and ground cover species in place in 1990, only five species were from the Shipman period or earlier, including three tree peonies and two mature deciduous trees, white oak (Quercus alba) and black tupelo (Nyssa sylvatica). The existing plant material within the garden in 1990, G. Doell and C. Doell noted, "failed to convey not only the form, color, scale and texture of the plant composition intended by Mrs. Shipman, but also the three-dimensional spatial qualities of the garden."

\section{Preservation approach and treatment plan}

By definition, the goal of historic preservation is to manage change over time. No single management strategy can be applied in all situations; so tailor- 

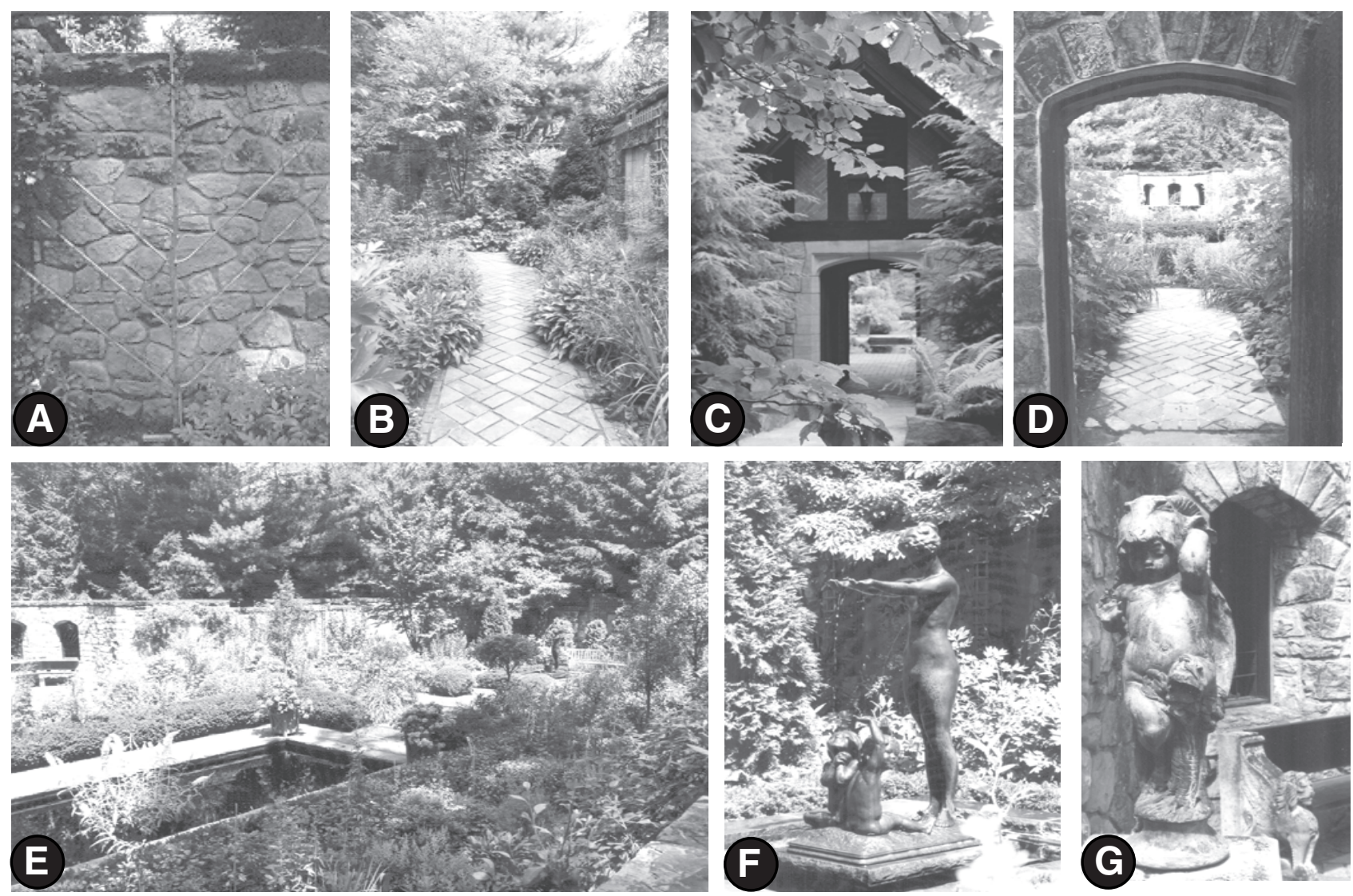

Fig. 7. This composite photograph documents the major historic features of the English Garden at Stan Hywet Hall and Gardens, Akron, Ohio, as it appeared in 2002. The English Garden is one of several garden rooms on the estate designed by Warren Manning, landscape architect, in collaboration with architect Charles Schneider. Manning's 1917 design concept for the English Garden was a walled, hidden flower garden in the Arts and Crafts style. In 1928, the Seiberlings commissioned Ellen Biddle Shipman, landscape architect, to redesign the English Garden. In 1992, the restoration of the English Garden to Shipman's design specifications was completed. Design elements of the garden attributed to Warren Manning are shown: (A) interior walls with trellises; (B) brick walkways; (C) main entrance; (D) side entrance; (E) an overview of the reflecting pool and western wall; (F) the bronze fountain/statue group by Willard D. Paddock; (G) small lead statue representing one of the four seasons. The plantings seen within the garden are those specified by Shipman and planted in 1991 for the garden's restoration to Shipman's 1928 design. Photographs by the author.

ing a landscape preservation program to meet the needs of each historic site is essential (Page et al., 1998). The selection of a primary treatment for a landscape establishes an overall historic preservation approach, as well as a philosophical framework from which to operate (Birnbaum, 1994). In developing the preservation concept for the English Garden at Stan Hywet Hall and Gardens, there were four major considerations: 1 ) historical and design significance of the garden; 2) the quality and detail of the research base; 3 ) the integrity of the landscape; 4) the stated purposes and policies of the institution; and 5) the contemporary needs of Stan Hywet Hall and Gardens (G. Doell and C. Doell, unpublished report). The first three of these have been presented already. The fourth consideration refers to Stan Hywet
Hall and Gardens Foundation's policy statement on preservation goals: "to preserve, restore, and maintain the gardens and grounds of Stan Hywet Hall and Gardens according to the plan of Warren Manning and Frank and Gertrude Seiberling. Using plans, letters, photographs, and other data, every effort should be made to protect the historically significant garden landscape from change." In 1990, the policy was amended to establish the period of greatest historical significance for the restoration of Stan Hywet Hall and Gardens' landscape as 1912-30. The fifth consideration, the "contemporary needs of Stan Hywet Hall and Gardens," refers to the operation of Stan Hywet Hall and Gardens as a museum with unique interpretative objectives for the estate.

Preservation concept. The time period of 1912 to 1930 is both the period of greatest historical significance for restoration of Stan Hywet Hall and Gardens' landscape and Manning's architectural design for the English Garden. The garden's structural integrity and the archival evidence of Manning's plant list for the English Garden were strong reasons to suggest that the English Garden should be restored to Manning's design. The difficulty in achieving an accurate restoration of Manning's design for the garden was the lack of a planting plan by Manning. Any restoration based on Manning's plant list would require "considerable conjecture" as to the arrangement of those plants within the garden-a problem for achieving the degree of historical integrity required by the accepted processes for historic preservation (G. Doell and C. Doell, 


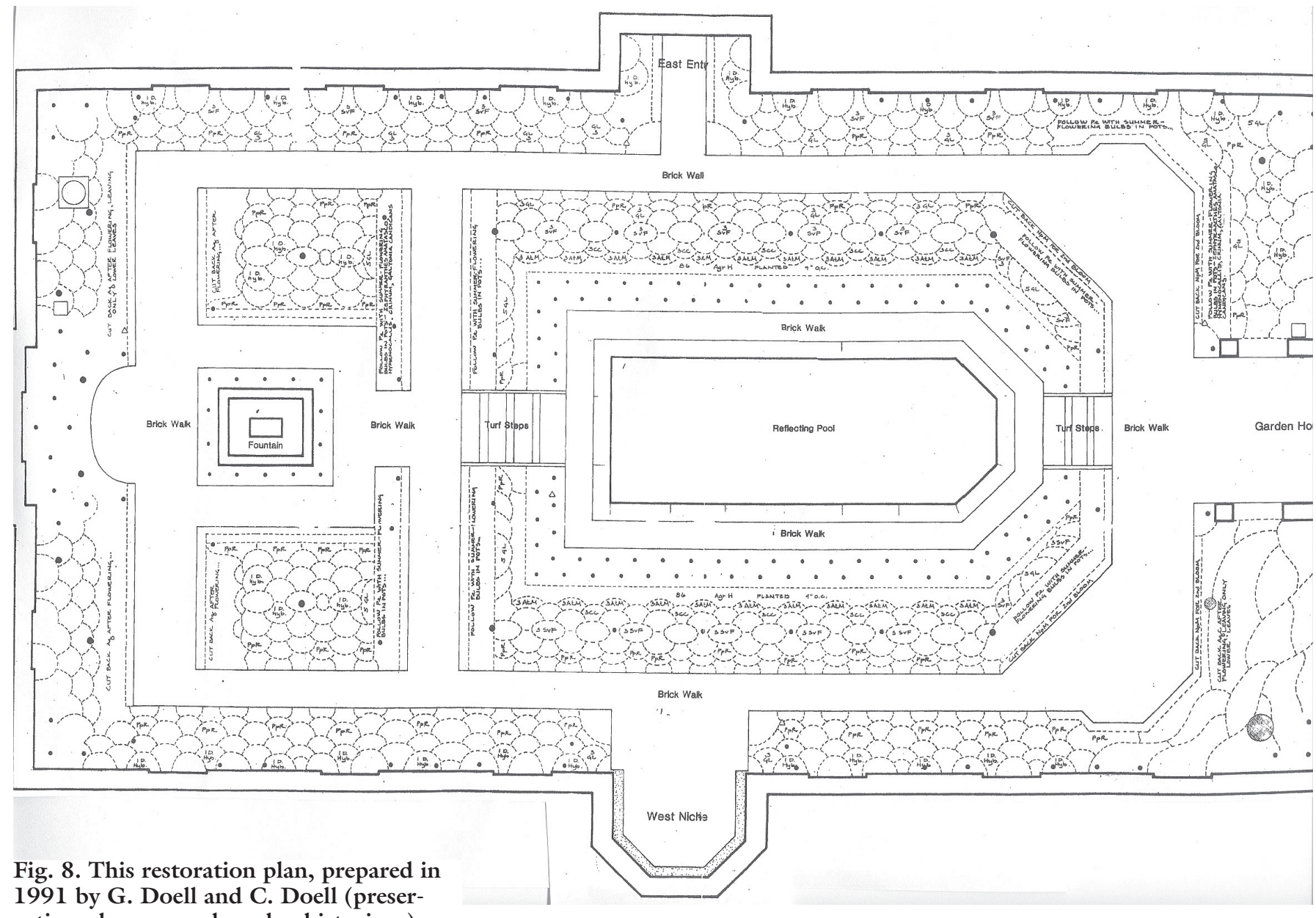
1991 by G. Doell and C. Doell (preservation planners and garden historians), documents the layout of the garden walls, walks, pools, niches, and entrances of the English Garden at Stan Hywet Hall and Gardens, Akron, Ohio. This representation of the garden is oriented with the main garden entrance (south) on the right. The English Garden is one of several garden rooms on the estate designed by Warren Manning, landscape architect, in collaboration with architect Charles Schneider. Manning's 1917 design concept for the English Garden was a walled, hidden flower garden in the Arts and Crafts style. In 1928, the Seiberlings commissioned Ellen Biddle Shipman, landscape architect, to redesign the English Garden. The garden is longer on its north to south axis $[60 \times 120 \mathrm{ft}(18.3 \times 36.6 \mathrm{~m})]$ and is completely enclosed by 8 - $\mathrm{ft}(2.4 \mathrm{~m})$ stone walls. Walls on the west and south sides are freestanding, whereas walls on the east and north retain up to $6 \mathrm{ft}(1.8 \mathrm{~m})$ of soil, creating the effect of a sunken garden. The design layout created by Warren Manning is a formal cross-axial design with two entrances. The side entry is on the east side and the main entrance is on the south side. Ellen Biddle Shipman's fan-shaped groupings of perennials were reproduced using a template, thus restoring her placement specifications exactly. (@Stan Hywet Hall and Gardens, Akron, Ohio)

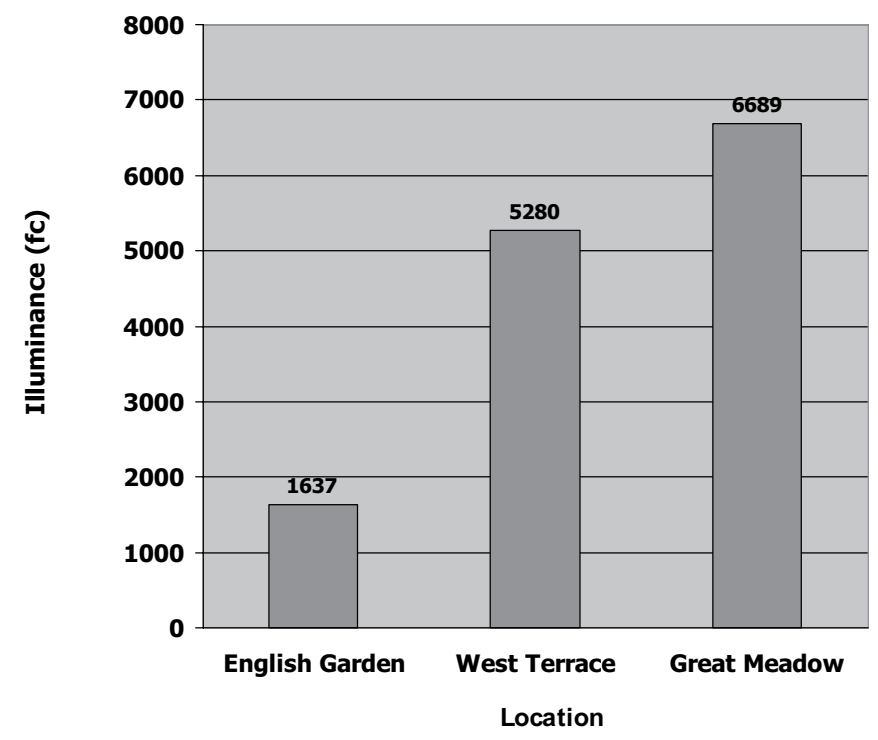

Fig. 9. Average illuminance values for the Great Meadow, West Terrace, and the English Garden as measured in 1990, prior to restoration of the English Garden at Stan Hywet Hall and Gardens in Akron, Ohio. (For more background, see text and caption for Fig. 8.) In 1928, landscape architect Ellen Biddle Shipman was commissioned to redesign the English Garden. In 1992, the restoration of the English Garden to Shipman's design specifications was completed. Existing light conditions were determined for the English Garden in comparison to other areas of the estate that were open (Great Meadow) or less shaded (West Terrace). $(1 \mathrm{fc}=10.76 \mathrm{lux}$ ) 


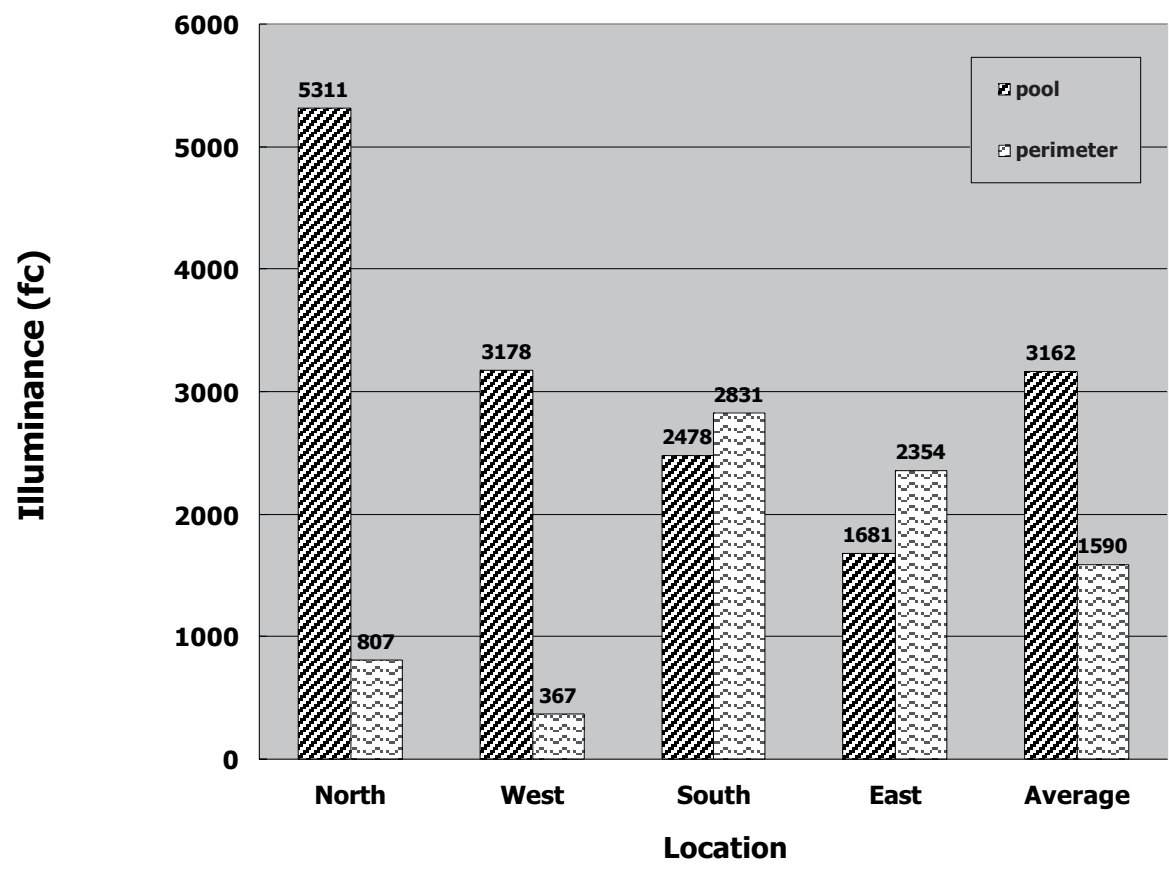

Fig. 10. Average illuminance values at different locations within the English Garden as measured in 1990, prior to restoration of the English Garden at Stan Hywet Hall and Gardens in Akron, Ohio. (For more background, see text and caption for Fig. 8.) In 1928, landscape architect Ellen Biddle Shipman was commissioned to redesign the English Garden. In 1992, the restoration of the English Garden to Shipman's design specifications was completed. Existing light conditions were determined at 16 locations throughout the interior of the garden (eight on the perimeter paths and eight along the walkway surrounding the reflecting pool). ( $1 \mathrm{fc}=10.76 \mathrm{lux})$

unpublished report). Specifically, the guidelines recommend against "installing vegetation that was thought to have existed during the restoration period, but for which there is insufficient documentation" (Birnbaum and Peters, 1996). While few of Shipman's plants remained in the garden by 1989 , Shipman's detailed planting plans and historic photographs provided excellent documentation for the restoration of her design contribution. While the historic period of Shipman's design was inconsistent with the restoration policy, there were two definite advantages of a preservation concept based on a Shipman restoration: 1) it provides for a more accurate representation of the garden during a particular period in its history (1929-46); and 2) it enables Stan Hywet Hall and Gardens as a museum to incorporate the creative contributions of Manning and Shipman, as the major designers; Willard Paddock, the sculptor; and the artistic patronage of the Seiberlings themselves, into the garden's interpretive theme.

The final preservation concept for the English Garden recommended by
G. Doell and C. Doell and endorsed by the Garden/Landscape Committee of Stan Hywet Hall and Gardens in 1990 had two components: 1) restore the plant composition within the English Garden based on Shipman's planting plans and surviving period photographs and, as appropriate, Manning's plant list, so that the garden's visual and spatial qualities are more expressive of the Seiberling residency (1929-46), and 2) restore the perimeter plantings surrounding the English Garden to their appearance during the Seiberling residency (1929-46), so that they fulfill Manning's design intent as a screen for the walls and a backdrop for the West Terrace. In essence, the interior plantings would be restored to the highest degree of integrity possible according to Shipman's plans and the perimeter of evergreens surrounding the English Garden would be restored according to Manning's design.

AdDitional CONSIDERATIONS. Successful restoration of Shipman's plan would depend on light conditions within the garden. Trees in the outer perimeter (norway spruce, canadian hemlock), $50 \mathrm{ft}(15.3 \mathrm{~m})$ taller than in 1928 when they were planted, cast dense shade throughout the garden during most of the year. These conditions were not suitable for the optimum growth or long-term survivability of the perennial species specified by Shipman as $60 \%$ of those plants were categorized as full sun plants and $40 \%$ as shade tolerant. For this reason, most of these trees in the garden's outer perimeter were recommended for removal and replacement, in order to: 1) improve cultural conditions for the flower garden and reinforce Shipman's design intent for the interior, and 2) enhance Manning's original design intent for the perimeter plantings to effectively screen the garden.

Treatment plan. Historic restoration attempts to recapture the appearance of a landscape at a particular point in time, as confirmed by detailed historic documentation. When the most important goal is to portray a landscape and its character-defining features at an exact period of time, restoration is selected as the primary treatment, rather than preservation, rehabilitation or reconstruction (Birnbaum, 1994). Based on historic documentation and research, recommendations for a comprehensive horticultural restoration of the English Garden consisted of seven major steps or phases (Table 4) (G. Doell and C. Doell, unpublished report).

\section{Restoration processes}

In the spring and summer of 1991, the English Garden plantings were restored to the specifications of Ellen Biddle Shipman's shrub and perennial planting plans. Many of the perennial species called for by Shipman in 1928 were no longer available commercially or were available only through nurseries specializing in historic plants. For the English Garden planting, a list of modern substitutes was created based on physical descriptors of the plants specified on Shipman's plans (Table 5 ). Accurate placement of nearly 1500 perennial plants on Shipman's planting plans was accomplished by using an enlarged copy of the planting plan as a template that was superimposed over the planting beds. Plantings on the garden's outer perimeter were restored to Manning's design specifications so that the garden walls were once again hidden from view. Nearly all of the evergreen trees in the perimeter 
Table 4. Recommendations for the horticultural restoration of plantings within and immediately outside the English Garden at Stan Hywet Hall and Gardens, Akron, Ohio, developed by G. Doell and C. Doell in 1990. Stan Hywet Hall and Gardens was the home of the Seiberling family from 1917 until 1955 when it was incorporated as a nonprofit museum open to the public. The English Garden is one of several garden rooms on the estate designed by Warren Manning, landscape architect, in collaboration with architect Charles Schneider. Manning's 1917 design concept for the English Garden was a walled, hidden flower garden in the Arts and Crafts style. In 1928, the Seiberlings commissioned Ellen Biddle Shipman, landscape architect, to redesign the English Garden. In 1992, the restoration of the English Garden to Shipman's design specifications was completed.

Major processes (1-7) and related explanations $(a, b, c, \ldots)$

1. Remove all nonhistoric and non-contributing ${ }^{z}$ trees, shrubs, vines and groundcovers within garden.

a. These volunteer and/or other plant materials generally not original to the Manning/Shipman/Seiberling periody are indicated on the Analysis and Recommendations plan. ${ }^{\mathrm{x}}$

2. Remove all nonhistoric and noncontributing ${ }^{z}$ trees, shrubs, vines and groundcovers from the perimeter screen planting.

a. These volunteer and/or other plant materials generally not original to the Manning/Shipman/Seiberling period are indicated on the Analysis and Recommendations plan. ${ }^{x}$

3. Protect ${ }^{\mathrm{w}}$ the mature trees and shrubs that are to be retained for the restoration.

a. These materials, indicated on the Analysis and Recommendations plan ${ }^{x}$, include the tree peonies, white oak, and black tupelo within the English Garden and the hardwood trees at the perimeter. ${ }^{\mathrm{v}}$

b. Monitor the condition of trees and shrubs and initiate, as necessary, pruning, fertilizing, cabling, and other types of care under the direction of a certified arborist or similarly qualified individual. When replacement is necessary, choose the same type and location as original.

c. It would be beneficial to reduce the extent of the tree canopy that overhangs the garden, to the degree possible, so that light and rainfall may penetrate more easily.

4. Remove and replace the overgrown evergreens that comprise the perimeter screen planting around the English Garden.

a. Historic trees that are in fair or poor condition or have outgrown their usefulness as a screen should be removed and replaced, including those canadian hemlock, norway spruce, and white pine identified on the Analysis and Recommendations plan. ${ }^{x}$

b. Interplant with additional trees, as necessary, to restore the evergreen backdrop between the West Terrace and the English Garden and screens along the southeast corner and western edge of the English Garden.

c. When tree work is performed, record the number of annual growth rings, together with the diameter and circumference of trunks/major limbs which are removed.

5. Initiate a multi-year program to rejuvenate the rhododendrons and mountain-laurels at the perimeter of the English Garden.

a. These materials, installed as a shrubby understory for the norway spruce and canadian hemlock, are original to the Manning/Shipman/Seiberling period. ${ }^{y}$

b. Interplant with additional shrubs, as necessary.

6. Restore ${ }^{u}$ the trees, shrubs, and herbaceous plantings indicated on the Shipman plans so that visual and spatial qualities of the English Garden are more expressive of the Seiberling residency (1929-46). ${ }^{\text {t }}$

a. Historical research indicates that the trees and shrubs were installed as planned, with the possible exception of two hawthorns (Crataegus spp.) in the vicinity of the pool. These trees should not be restored unless their presence is confirmed in historical photographs or other documentary resources yet to be found.

7. Restore the missing elements that Mrs. Shipman had retained from the earlier Manning/Seiberling garden.

a. These include the espaliered pear trees, climbing roses, and vines on the interior walls of the garden; the potted plants surrounding the pool; and arbor seats.

\footnotetext{
${ }^{2}$ Noncontributing materials are plants that originated before or after the period of significance and detract from the design intent for the garden.

yefined as the period of time (1917-46) starting with Manning's design (1917), followed by Shipman's redesign (1928), and lasting until the English Garden began to decline due to poor maintenance (1946).

${ }^{x}$ Analysis and Recommendations plan was part of the graphic plans prepared by G. Doell and C. Doell that documented existing conditions in the English Garden prior to restoration.

"Protection is defined as "the act or process of applying measures designed to affect the physical condition of a property by defending or guarding it from deterioration, loss, or attack, or to cover or shield the property from danger or injury."

"Perimeter refers to the planting area outside the enclosing stone walls of the garden composed of a mix of evergreen trees, (canadian hemlock, norway spruce, white pine) and deciduous trees, (tuliptree) and shrubs (deutzia, sweet mockorange, viburnum, spicebush, rhododendron, mountain-laurel).

"Restoration is defined in Table 2.

tRefers to those years of the Seiberling residency that coincide with the preservation concept for the English Garden.
}

planting beds were removed prior to restoring the interior English Garden plantings. Younger, smaller trees of the same species (norway spruce, canadian hemlock) were replanted in place of the trees that were removed; whereas most of the white pine trees, whose narrow canopies and fine-textured needles cast little shade, were left in place. The fully restored garden was opened to the public in the summer of 1992 .

\section{Long-term planning}

G. Doell and C. Doell recommended that a long-term maintenance plan be prepared for the English Garden and its landscape setting in order to 1) communicate the design intent of the garden features; 2) establish specialized horticultural practices such as espalier, training to standards, and hedge trimming; 3 ) prevent subsequent deterioration and decline of the plantings; and 4) protect public health and safety on the site. Preservation maintenance, an integral part of preservation planning, is the practice of monitoring and controlling change in the landscape to ensure that its historic 
Table 5. Plant species and cultivars specified by Ellen Biddle Shipman's 1929 perennial planting plan and the list of historic varieties and modern substitutes developed for use in the restoration of the English Garden plantings at Stan Hywet Hall and Gardens ${ }^{z}$ in Akron, Ohio, in 1990-91. Stan Hywet Hall and Gardens was the home of F.A. Seiberling (founder of Goodyear Tire and Rubber Co.) his wife, Gertrude, and their children from 1917 until 1955 when it was incorporated as a nonprofit museum open to the public. The English Garden is one of several garden rooms on the estate designed by Warren Manning, a renowned landscape architect from Boston, in collaboration with architect Charles Schneider. Manning's 1917 design concept for the English Garden was a walled, hidden flower garden in the Arts and Crafts style. In 1928, the Seiberlings commissioned Ellen Biddle Shipman to redesign the English Garden. Modern substitutes were selected based on descriptions of plants specified on Shipman's plan that were not available commercially.

\begin{tabular}{|c|c|c|c|}
\hline Common name & $\begin{array}{l}\text { Plants specified } \\
\text { by Shipman }\end{array}$ & $\begin{array}{l}\text { Historic varieties and } \\
\text { modern substitutes }\end{array}$ & Synonyms, plant description, and notes ${ }^{y}$ \\
\hline azure monkshood & Aconitum carmichaelii & Aconitum carmichaelii & $\begin{array}{l}\text { [synonym } A \text {. fischeri] } 48 \text { inches }^{y} \text { high with violet blue } \\
\text { flowers in fall }\end{array}$ \\
\hline autumn monkshood & Aconitum benryi & $\begin{array}{l}\text { Aconitum henryi } \\
\text { 'Sparkes Variety' }\end{array}$ & 48 inches high, violet flower in summer \\
\hline bugle-weed & Ajuga reptans & Ajuga reptans & 6 inches high, blue flowers in spring; green leaves \\
\hline bugloss & $\begin{array}{l}\text { Anchusa azurea } \\
\text { Dropmore' }\end{array}$ & $\begin{array}{l}\text { Anchusa azurea } \\
\text { 'Lodden Royalist' }\end{array}$ & $\begin{array}{l}\text { [synonym } A \text {. italica] to } 48 \text { inches high, deep blue } \\
\text { flowers in spring; coarse hairy foliage }\end{array}$ \\
\hline japanese anemone & Anemone hupehensis & Anemone hupehensis & to 24 inches high with rosy flowers in fall \\
\hline japanese anemone & Anemone $\times$ bybrida & Anemone $\times$ bybrida & $\begin{array}{l}\text { [synonym } A \text {. japonica }] 30-42 \text { inches with pink } \\
\text { 'September Charm' flowers in fall }\end{array}$ \\
\hline japanese anemone & $\begin{array}{l}\text { Anemone } \times \text { bybrida } \\
\text { 'Alba' }\end{array}$ & Anemone $\times$ bybrida 'Alba' & $\begin{array}{l}\text { [synonym A. japonica 'Alba'] } 30-42 \text { inches high with } \\
\text { clear, white } 2-3 \text { inch single flowers in fall }\end{array}$ \\
\hline st.-bernard-lily & Anthericum liliago & Anthericum liliago & $\begin{array}{l}24 \text { inches high with white flowers in summer; grassy } \\
\text { green leaves }\end{array}$ \\
\hline columbine & Aquilegia chrysantha & Aquilegia chrysantha & $\begin{array}{l}30 \text { inches high with golden-yellow, long-spurred } \\
\text { flowers in late spring }\end{array}$ \\
\hline columbine & $\begin{array}{l}\text { Aquilegia } \times \text { bybrida } \\
\text { 'Blue shades' }\end{array}$ & Aquilegia $\times$ bybrida & $\begin{array}{l}\text { named variety/cultivar not specified; typical } \\
\text { appropriate features; long spurred flowers, blue, pink } \\
\text { and/or white flowers }\end{array}$ \\
\hline rock-cress & Arabis albida & Arabis albida 'Florepeno' & $\begin{array}{l}\text { [synonym } A \text {. caucasica; } A \text {. alpina }] 8 \text { inches high with } \\
\text { white flowers in spring; evergreen leaves }\end{array}$ \\
\hline white mugwort & Artemisia lactiflora & Artemisia lactiflora & $\begin{array}{l}60 \text { inches high with white plumes in late summer; } \\
\text { green jagged leaves }\end{array}$ \\
\hline blue wood aster & Aster cordifolius & Aster cordifolius & $\begin{array}{l}48 \text { inches high with violet-blue flowers in fall; } \\
\text { heart-shaped leaves }\end{array}$ \\
\hline aster & Aster laevis & Aster laevis & 48 inches high with pale blue flowers in late summer \\
\hline new england aster & $\begin{array}{l}\text { Aster novae-angliae } \\
\quad \text { roseus }\end{array}$ & $\begin{array}{l}\text { Aster novae-angliae } \\
\text { 'Honeysong Pink' }\end{array}$ & $48-72$ inches high with single pink flowers \\
\hline new york aster & $\begin{array}{l}\text { Aster novi-belgi } \\
\text { 'Beauty of Colwell' }\end{array}$ & $\begin{array}{l}\text { Aster novi-belgi } \\
\text { 'Ada Ballard' }\end{array}$ & $\begin{array}{l}40 \text { inches high with semi-double lavender-blue } \\
\text { flowers in fall }\end{array}$ \\
\hline new york aster & $\begin{array}{l}\text { Aster novi-belgi } \\
\text { Climax' }\end{array}$ & Aster novi-belgi 'Climax' & $\begin{array}{l}48-60 \text { inches high with light lavender to blue } \\
\text { flowers in fall }\end{array}$ \\
\hline new york aster & $\begin{array}{l}\text { Aster novi-belgi } \\
\text { 'Lady Lloyd' }\end{array}$ & $\begin{array}{l}\text { Aster novi-belgi } \\
\text { 'Patricia Ballard' }\end{array}$ & $\begin{array}{l}\text { 36-48 inches high with rose-pink with purple sheen in } \\
\text { fall }\end{array}$ \\
\hline new york aster & $\begin{array}{l}\text { Aster novi-belgi } \\
\text { 'King of Belgians' }\end{array}$ & Aster novi-belgi 'Eventide' & $\begin{array}{l}60 \text { inches high with semi-double lavender flowers } \\
\text { in fall }\end{array}$ \\
\hline new york aster & $\begin{array}{l}\text { Aster novi-belgi } \\
\text { 'Thomas Ware' }\end{array}$ & $\begin{array}{l}\text { Aster novi-belgi } \\
\text { 'Harrington's Pink' }\end{array}$ & 36-48 inches high with profuse pink flowers in fall \\
\hline astilbe & $\begin{array}{l}\text { Astilbe } \times \text { arendsii } \\
\text { Brunhilde' }\end{array}$ & $\begin{array}{l}\text { Astilbe } \times \text { arendsii } \\
\text { 'Hyacinth' }\end{array}$ & $\begin{array}{l}\text { to } 48 \text { inches high with pink flowers; lilac in late spring } \\
\text { to early summer }\end{array}$ \\
\hline astilbe & Astilbe 'Gruno' & Astilbe 'Ostrich Plume' & $\begin{array}{l}\text { to } 48 \text { inches high with salmon pink flowers in late } \\
\text { spring to early summer }\end{array}$ \\
\hline astilbe & Astilbe & $\begin{array}{l}\text { Astilbe } \times \text { arendsii } \\
\text { 'Cattleya' }\end{array}$ & $\begin{array}{l}\text { named variety/cultivar not specified; typical appropriate } \\
\text { features (36 inches high with rose pink flowers) }\end{array}$ \\
\hline false indigo & Baptisia australis & Baptisia australis & $\begin{array}{l}48 \text { inches high with indigo flowers in late spring; black } \\
\text { seed pods; gray green pea-like leaves }\end{array}$ \\
\hline boltonia & Boltonia asteroides & $\begin{array}{l}\text { Boltonia asteroides } \\
\text { 'Snowbank' }\end{array}$ & 36-48 inches high with white daisy flowers in fall \\
\hline boltonia & Boltonia latisquama & $\begin{array}{l}\text { Boltonia asteroides } \\
\text { Pink Beauty' }\end{array}$ & 36-60 inches high with 1-inch pink to purple flowers \\
\hline
\end{tabular}

Table 5 continued on next page. 
Table 5. Continued from previous page.

\begin{tabular}{|c|c|c|c|}
\hline Common name & $\begin{array}{l}\text { Plants specified } \\
\text { by Shipman }\end{array}$ & $\begin{array}{l}\text { Historic varieties and } \\
\text { modern substitutes }\end{array}$ & Synonyms, plant description, and notes \\
\hline brunnera & Brunnera macrophylla & Brunnera macrophylla & $\begin{array}{l}18 \text { inches high with blue flowers in spring; coarse } \\
\text { heart-shaped leaves }\end{array}$ \\
\hline canterbury bells & Campanula medium & $\begin{array}{l}\text { Campanula medium } \\
\text { 'Calycanthema' }\end{array}$ & $\begin{array}{l}\text { 24-36 inches high with cup and saucer white, } \\
\text { white, blue, lavender and rose flowers in summer }\end{array}$ \\
\hline bellflower & Campanula perscifolia & Campanula perscifolia & $\begin{array}{l}36 \text { inches high with blue flowers in early summer; } \\
\text { semi-evergreen tufts of foliage }\end{array}$ \\
\hline common pyrethrum & $\begin{array}{l}\text { Chrysanthemum } \\
\text { coccineum }\end{array}$ & $\begin{array}{l}\text { Chrysanthemum coccineum } \\
\text { 'Robinson's Roseum' }\end{array}$ & $\begin{array}{l}24 \text { inches high with mixed daisy flowers in summer; } \\
\text { summer; ferny green leaves }\end{array}$ \\
\hline high daisy & $\begin{array}{l}\text { Chrysanthemum } \\
\text { serotinum }\end{array}$ & Chrysanthemum serotinum & $\begin{array}{l}\text { [synonym C. uliginosum] } 48-78 \text { inches high } \\
\text { with clustered white flowers with green } \\
\text { centers in the fall; coarse-toothed leaves }\end{array}$ \\
\hline max daisy & $\begin{array}{l}\text { Chrysanthemum } \\
\text { ×superbus }\end{array}$ & $\begin{array}{l}\text { Chrysanthemum } \\
\quad \times \text { superbus 'Alaska' }\end{array}$ & $\begin{array}{l}\text { [synonym C. maximum] } 24-36 \text { inches high } \\
\text { with } 2-3 \text { inch, single white flowers in summer }\end{array}$ \\
\hline black snakeroot & Cimicifuga racemosa & Cimicifuga racemosa & $\begin{array}{l}60 \text { inches high with white wands of flowers } \\
\text { in summer }\end{array}$ \\
\hline clematis & Clematis heracleifolia & $\begin{array}{l}\text { Clematis heracleifolia } \\
\text { 'Robert Brydon' }\end{array}$ & $\begin{array}{l}\text { 24-36 inches high, subshrub with tubular } \\
\text { hyacinth-blue flowers }\end{array}$ \\
\hline dahlia & Dablia & Dablia Eveline' & $\begin{array}{l}\text { named cultivar/variety not specified; typical } \\
\text { appropriate features; tall varieties }(36-60 \\
\text { inches high) with pale yellow or white } \\
\text { flowers less than } 4 \text { inches }\end{array}$ \\
\hline garland larkspur & $\begin{array}{l}\text { Delphinium } \\
\quad \times \text { belledonna }\end{array}$ & $\begin{array}{l}\text { Delphinium } \times \text { belledonna } \\
\text { Bellamosum? }\end{array}$ & $\begin{array}{l}\text { [synonym D. formosum] 36-48 inches high } \\
\text { with blue flowers }\end{array}$ \\
\hline candle larkspur & Delphinium $\times$ elatum & $\begin{array}{l}\text { Delphinium xelatum } \\
\text { 'King Arthur', 'Guinevere', } \\
\text { 'Summer Skies' }\end{array}$ & $\begin{array}{l}\text { named cultivar/variety not specified; typical } \\
\text { appropriate features; } 48-96 \text { inches high } \\
\text { with shades of blue }\end{array}$ \\
\hline sweet william & Dianthus barbatus & $\begin{array}{l}\text { Dianthus barbatus 'Albus', } \\
\text { 'Pink Beauty' }\end{array}$ & $\begin{array}{l}12 \text { inches high; mixed shades of bright pink, } \\
\text { red and white flowers; dark green leaves; pink } \\
\text { flowers preferred }\end{array}$ \\
\hline cottage pink & Dianthus plumarius & $\begin{array}{l}\text { Dianthus plumarius } \\
\text { 'Spring Beauty' }\end{array}$ & $\begin{array}{l}15 \text { inches high; purplish-fringed white, pink, } \\
\text { and rose flowers; leaves narrow and gray }\end{array}$ \\
\hline bleeding-heart & Dicentra spectabilis & Dicentra spectabilis & $\begin{array}{l}6 \text { inches high with rosy-red hearts; gray-green } \\
\text { divided leaves dying back in midsummer }\end{array}$ \\
\hline dittany & Dictamnus albus & Dictamnus albus & $\begin{array}{l}\text { [synonym D. fraxinella] } 36 \text { inches high with } \\
\text { white flowers; long stamens in early summer; } \\
\text { leaves dark green divided with citrus odor }\end{array}$ \\
\hline common foxglove & $\begin{array}{l}\text { Digitalis purpurea } \\
\text { 'Alba', }\end{array}$ & Digitalis purpurea 'Alba' & $\begin{array}{l}48-50 \text { inches high with white nodding flowers, } \\
\text { spotted inside }\end{array}$ \\
\hline leopards-bane & Doronicum caucasicum & $\begin{array}{l}\text { Doronicum caucasicum } \\
\text { 'Miss Mason' }\end{array}$ & $\begin{array}{l}\text { 12-24 inches high with bright yellow daisies in } \\
\text { spring; leaves heart-shaped with scalloped edges }\end{array}$ \\
\hline desert-candle & Eremurus robustus & Eremurus robustus & $\begin{array}{l}84 \text { inches high with clear pink flowers with } \\
\text { brownish blotch at base in late spring }\end{array}$ \\
\hline fleabane & Erigeron speciosus & Erigeron speciosus 'Blue Beauty' & 24 inches high with violet-blue flowers in summer \\
\hline mist-flower & Eupatorium coelestinum & Eupatorium coelestinum & $\begin{array}{l}36 \text { inches high with violet-blue flowers in fall; } \\
\text { green toothed leaves; can be invasive }\end{array}$ \\
\hline white snakeroot & Eupatorium rugosum & Eupatorium rugosum & $\begin{array}{l}\text { [synonym E. urticaefolium] } 36 \text { inches high } \\
\text { with white clustered flowers in summer; } \\
\text { leaves sharply toothed }\end{array}$ \\
\hline lady fern & Ferns & Athyruim felixfemina & $\begin{array}{l}\text { variety not specified; Athyrium chosen from } \\
\text { Warren Manning list }\end{array}$ \\
\hline gladiolus & Gladiolus & $\begin{array}{l}\text { Gladiolus 'Butter Cup', } \\
\text { Easter Time' }\end{array}$ & $\begin{array}{l}\text { garden hybrids; tall } 36 \text { inches cultivars with } \\
\text { flowers of pale yellow or white }\end{array}$ \\
\hline babys-breath & Gypsophila paniculata & $\begin{array}{l}\text { Gypsophila paniculata } \\
\text { 'Bristol Fairy' }\end{array}$ & $\begin{array}{l}24-36 \text { inches high with tiny single or } \\
\text { double white flowers in summer; small gray leave }\end{array}$ \\
\hline $\begin{array}{l}\text { common yellow } \\
\text { day-lily }\end{array}$ & $\begin{array}{l}\text { Hemerocallis lilio- } \\
\text { asphodelus }\end{array}$ & Hemerocallis flava & $\begin{array}{l}\text { [synonym } H \text {. flava] } 30-36 \text { inches high with } \\
\text { yellow fragrant flowers in late spring }\end{array}$ \\
\hline late yellow day-lily & Hemerocallis thunbergi & Hemerocallis citrina & $\begin{array}{l}\text { similar to H. lilio-asphodelus but with flowers } \\
\text { opening at night }\end{array}$ \\
\hline
\end{tabular}

Table 5 continued on next page. 
Table 5. Continued from previous page.

\begin{tabular}{|c|c|c|c|}
\hline Common name & $\begin{array}{l}\text { Plants specified } \\
\text { by Shipman }\end{array}$ & $\begin{array}{l}\text { Historic varieties and } \\
\text { modern substitutes }\end{array}$ & Synonyms, plant description, and notes \\
\hline coral bells & Heuchera sanguinea & $\begin{array}{l}\text { Heuchera sanguinea } \\
\text { Chatterbox }\end{array}$ & $\begin{array}{l}18 \text { inches high with bright red flowers in early } \\
\text { summer, rounded lobed leaves; reddish fall color; } \\
\text { color not specified, pink appropriate }\end{array}$ \\
\hline rose-mallow & Hibiscus moschentos & $\begin{array}{l}\text { Hibiscus moscheutos } \\
\text { 'Lords Pink' }\end{array}$ & $\begin{array}{l}84 \text { inches high with large white, rose or pink } \\
\text { flowers in midsummer }\end{array}$ \\
\hline $\begin{array}{l}\text { narrow-leaved } \\
\text { plaintain-lily }\end{array}$ & Hosta lancifolia & Hosta lancifolia & $\begin{array}{l}24 \text { inches high with lilac flower spikes in late summer, } \\
\text { green with wavy edges }\end{array}$ \\
\hline $\begin{array}{l}\text { fragrant } \\
\text { plaintain-lily }\end{array}$ & $\begin{array}{l}\text { Hosta plantaginea } \\
\text { 'Grandiflora' }\end{array}$ & $\begin{array}{l}\text { Hosta plantaginea } \\
\text { 'Grandiflora' }\end{array}$ & $\begin{array}{l}24-30 \text { inches high with white fragrant flowers in } \\
\text { fall, large, heart-shaped yellow-orange leaves }\end{array}$ \\
\hline german iris & $\begin{array}{l}\text { Iris germanica } \\
\text { 'Ambassadeur' }\end{array}$ & $\begin{array}{l}\text { Iris germanica } \\
\text { 'Gay Parasol' }\end{array}$ & $\begin{array}{l}46 \text { inches high; clouded, reddish-violet; falls } \\
\text { velvety, dark reddish-violet with orange beard }\end{array}$ \\
\hline german iris & $\begin{array}{l}\text { Iris germanica } \\
\text { 'Cecil Minturn' }\end{array}$ & $\begin{array}{l}\text { Iris germanica } \\
\text { 'Prissy Miss' }\end{array}$ & 24-30 inches high; uniform shade of cattleya rose \\
\hline german iris & $\begin{array}{l}\text { Iris germanica 'Crusader' } \\
\text { 'Cabaret Royale' }\end{array}$ & Iris germanica & $\begin{array}{l}42 \text { inches high; standards light blue; falls deep } \\
\text { violet blue with orange-yellow beard }\end{array}$ \\
\hline german iris & Iris germanica 'Her Majesty' & Iris germanica Paradise' & $\begin{array}{l}32 \text { inches high; standards lilac-pink, falls lilac-pink, } \\
\text { veined crimson }\end{array}$ \\
\hline german iris & Iris germanica 'Isoline' & Iris germanica 'Stunning' & 36 inches high; standards lilac-pink; falls deeper \\
\hline german iris & $\begin{array}{l}\text { Iris germanica } \\
\text { 'Lords of June' }\end{array}$ & Iris germanica 'Full Tide' & $\begin{array}{l}40 \text { inches high; standards pale lavender-blue, } \\
\text { falls deeper }\end{array}$ \\
\hline german iris & $\begin{array}{l}\text { Iris germanica } \\
\text { 'Madame Chereau' }\end{array}$ & $\begin{array}{l}\text { Iris germanica } \\
\text { 'Madame Chereau' }\end{array}$ & $\begin{array}{l}32 \text { inches high; standards and falls clear, } \\
\text { white-frilled, azure-blue }\end{array}$ \\
\hline german iris & $\begin{array}{l}\text { Iris germanica } \\
\text { 'Queen Caterina' }\end{array}$ & $\begin{array}{l}\text { Iris germanica } \\
\text { Noteworthy }\end{array}$ & 36 inches high; standards and falls rosy-lavender \\
\hline german iris & $\begin{array}{l}\text { Iris germanica } \\
\text { 'Sheklnah' }\end{array}$ & $\begin{array}{l}\text { Iris germanica } \\
\text { 'Rising Moon' }\end{array}$ & $\begin{array}{l}36 \text { inches high; standards and falls soft lemon-yellow } \\
\text { with deep to rich yellow around orange beard }\end{array}$ \\
\hline japanese iris & $\begin{array}{l}\text { Iris kaempferi } \\
\text { 'Gold Bound' }\end{array}$ & $\begin{array}{l}\text { Iris kaempferi } \\
\text {.'Gold Bound' }\end{array}$ & double; white flowers with gold blotch \\
\hline japanese iris & Iris kaempferi Neptune' & Iris kaempferi 'Asagira' & single; violet, overlaid dark blue \\
\hline japanese iris & Iris kaempferi 'Painted Lady' & Iris kaempferi 'Chigagesho' & single; white, suffused and striped with bright pink \\
\hline japanese iris & Iris kaempferi 'Venus’ & Iris kaempferi Dace' & single; pure white \\
\hline iris & Iris pallida var. dalmatica & Iris pallida var. dalmatica & $\begin{array}{l}36 \text { inches high; standards and falls pale lavender; } \\
\text { fragrant }\end{array}$ \\
\hline goldband lily & Lilium auratum & Lilium auratum & $\begin{array}{l}72 \text { inches high with bowl-shaped, fragrant, upward- } \\
\text { facing flowers, white with crimson spots and } \\
\text { central gold stripe on each petal; blooms in } \\
\text { summer }\end{array}$ \\
\hline madonna lily & Lilium candidum & Lilium candidum & $\begin{array}{l}60 \text { inches high with pure white, fragrant, upward- } \\
\text { facing flowers in early summer }\end{array}$ \\
\hline regal lily & Lilium regale & Lilium regale & $\begin{array}{l}60 \text { inches high with white, fragrant, pendant flowers } \\
\text { with yellow throat and purple shading on outside; } \\
\text { blooms early summer }\end{array}$ \\
\hline lily & Lilium speciousum & Lilium speciousum 'Uchida' & $\begin{array}{l}60 \text { inches high with white fragrant nodding flowers } \\
\text { suffused with pink or red; relaxed petals; blooms } \\
\text { in late summer }\end{array}$ \\
\hline sea-lavendar & Limonium latifolium & Limonium latifolium & $\begin{array}{l}18 \text { inches high with lavender-blue sprays in summer; } \\
\text { semi-evergreen large leathery leaves }\end{array}$ \\
\hline lupine & Lupinus & $\begin{array}{l}\text { Lupinus Russell hybrids } \\
\text { 'Blue Shades' }\end{array}$ & $\begin{array}{l}36 \text { inches high with flowers in early summer; } \\
\text { color not specified, blue appropriate }\end{array}$ \\
\hline plume-poppy & Macleaya cordata & Macleaya cordata & $\begin{array}{l}96 \text { inches tall with panicles of cream flowers in } \\
\text { summer; large pubescent leaves; may be invasive }\end{array}$ \\
\hline true forget-me-not & Myosotis scorpoiodes & Myosotis scorpoiodes & 10 inches high with blue flowers in late spring \\
\hline nepeta & Nepeta mussini & Nepeta mussini & $\begin{array}{l}12 \text { inches high with violet-blue spikes in early } \\
\text { summer; downy gray aromatic leaves }\end{array}$ \\
\hline peony & Paeonia & $\begin{array}{l}\text { appropriate colors and } \\
\text { habit taken from Stan } \\
\text { Hywet Hall and Gardens } \\
\text { peony garden }\end{array}$ & $\begin{array}{l}\text { color not specified; } 48 \text { inches high with single } \\
\text { or double pink, dark pink or white flowers } \\
\text { in late spring }\end{array}$ \\
\hline
\end{tabular}

Table 5 continued on next page. 
Table 5. Continued from previous page.

\begin{tabular}{|c|c|c|c|}
\hline Common name & $\begin{array}{l}\text { Plants specified } \\
\text { by Shipman }\end{array}$ & $\begin{array}{l}\text { Historic varieties and } \\
\text { modern substitutes }\end{array}$ & Synonyms, plant description, and notes \\
\hline oriental poppy & $\begin{array}{l}\text { Papaver orientale } \\
\text { 'Mrs. Perry' }\end{array}$ & $\begin{array}{l}\text { Papaver orientale } \\
\text { 'Mrs. Perry' }\end{array}$ & $\begin{array}{l}\text { 18-36 inches high with salmon-pink flowers in } \\
\text { early summer }\end{array}$ \\
\hline penstemon & Penstemon heterophyllus & Penstemon grandiflorus & $\begin{array}{l}\text { P. heterophyllus, to } 60 \text { inches high with purple to } \\
\text { pinkish-blue flowers in summer; linear, shiny } \\
\text { leaves; tender }\end{array}$ \\
\hline penstemon & Penstemon unilateralis & Penstemon grandiflorus & $\begin{array}{l}24 \text { inches high with bright blue flowers in early } \\
\text { summer }\end{array}$ \\
\hline summer perennial phlox & $\begin{array}{l}\text { Phlox paniculata } \\
\text { 'C.B. Merrill' }\end{array}$ & $\begin{array}{l}\text { Phlox paniculata } \\
\text { 'White Admiral' }\end{array}$ & Probably tall white \\
\hline summer perennial phlox & $\begin{array}{l}\text { Phlox paniculata } \\
\text { Cameron' }\end{array}$ & $\begin{array}{l}\text { Phlox paniculata } \\
\text { 'Powder Puff' }\end{array}$ & Probably medium height; deep apple-blossom pink \\
\hline summer perennial phlox & $\begin{array}{l}\text { Phlox paniculata } \\
\text { 'Crepuscule' }\end{array}$ & $\begin{array}{l}\text { Phlox paniculata } \\
\text { 'Franz Schubert' }\end{array}$ & $\begin{array}{l}30 \text { inches high with soft lilac flowers with lighter } \\
\text { margins and crimson eye }\end{array}$ \\
\hline summer perennial phlox & $\begin{array}{l}\text { Phlox paniculata } \\
\text { 'Czarina' }\end{array}$ & $\begin{array}{l}\text { Phlox paniculata } \\
\text { 'World Peace' }\end{array}$ & Probably tall white \\
\hline summer perennial phlox & $\begin{array}{l}\text { Phlox paniculata } \\
\text { 'Dawn' }\end{array}$ & $\begin{array}{l}\text { Phlox paniculata } \\
\text { 'Dodo Hanbury Forbes' }\end{array}$ & $\begin{array}{l}\text { Probably medium height; shell pink with } \\
\text { inconspicuous carmine eye }\end{array}$ \\
\hline summer perennial phlox & Phlox paniculata Dolly' & Phlox paniculata 'Juliet' & Probably medium-short pink \\
\hline summer perennial phlox & $\begin{array}{l}\text { Phlox paniculata } \\
\text { 'Elizabeth Campbell' }\end{array}$ & $\begin{array}{l}\text { Phlox paniculata } \\
\text { 'Fairest One' }\end{array}$ & $\begin{array}{l}30 \text { inches high, with bright salmon-pink flowers } \\
\text { with lighter shadings and dark red eye }\end{array}$ \\
\hline summer perennial phlox & $\begin{array}{l}\text { Phlox paniculata } \\
\text { 'Eugene Danzan } \\
\text { Vielliers' }\end{array}$ & $\begin{array}{l}\text { Phlox paniculata } \\
\text { Eventide' }\end{array}$ & $\begin{array}{l}36 \text { inches high with soft lilac-blue flowers and } \\
\text { white center }\end{array}$ \\
\hline summer perennial phlox & $\begin{array}{l}\text { Phlox paniculata } \\
\text { 'Le Soleil' }\end{array}$ & $\begin{array}{l}\text { Phlox paniculata } \\
\text { 'Dresden China' }\end{array}$ & $\begin{array}{l}\text { Probably tall; soft rose flowers with darker } \\
\text { shaded eye }\end{array}$ \\
\hline summer perennial phlox & $\begin{array}{l}\text { Phlox paniculata } \\
\text { 'Mrs. Rea' }\end{array}$ & $\begin{array}{l}\text { Phlox paniculata } \\
\text { 'Mt. Fujiyama' }\end{array}$ & Probably tall white \\
\hline summer perennial phlox & $\begin{array}{l}\text { Phlox paniculata } \\
\text { 'Saison Lierval' }\end{array}$ & $\begin{array}{l}\text { Phlox paniculata } \\
\text { 'Prime Minister' }\end{array}$ & $\begin{array}{l}\text { Probably medium height; white flowers with } \\
\text { light pink center }\end{array}$ \\
\hline summer perennial phlox & $\begin{array}{l}\text { Phlox paniculata } \\
\text { 'Selma' }\end{array}$ & $\begin{array}{l}\text { Phlox paniculata } \\
\text { 'Eva Cullum' }\end{array}$ & $\begin{array}{l}36 \text { inches high with hydrangea pink flowers } \\
\text { and carmine eye }\end{array}$ \\
\hline summer perennial phlox & Phlox paniculata & $\begin{array}{l}\text { Phlox paniculata } \\
\text { 'Fairys Petticoat' }\end{array}$ & Probably medium pink \\
\hline primrose & Primula & Primula veris & $\begin{array}{l}\text { 6-10 inches high with various colored flowers } \\
\text { in spring, color not specified }\end{array}$ \\
\hline sage & Salvia farinacea & $\begin{array}{l}\text { Salvia farinacea } \\
\text { 'Blue Bedder' }\end{array}$ & $\begin{array}{l}36 \text { inches high with blue spikes in summer; } \\
\text { shiny oval gray-green leaves treat as annual }\end{array}$ \\
\hline stonecrop & Sedum spectabile & $\begin{array}{l}\text { Sedum spectabile } \\
\text { 'Autumn Joy' }\end{array}$ & $\begin{array}{l}18 \text { inches high with rosy-pink flat topped } \\
\text { clusters of flowers in late summer through } \\
\text { frost; gray-green leaves }\end{array}$ \\
\hline meadow-rue & $\begin{array}{l}\text { Thalictrum } \\
\text { aquilegifolium }\end{array}$ & $\begin{array}{l}\text { Thalictrum } \\
\text { aquilegifolium }\end{array}$ & $\begin{array}{l}\text { 24-36 inches high with rich reddish-purple, } \\
\text { fluffy flowers in early summer; light green } \\
\text { columbine-like leaves; nice pink seedheads }\end{array}$ \\
\hline meadow-rue & $\begin{array}{l}\text { Thalictrum } \\
\text { dipterocarpum }\end{array}$ & $\begin{array}{l}\text { Thalictrum } \\
\text { dipterocarpum }\end{array}$ & $\begin{array}{l}\text { 24-48 inches high with lilac flowers and pale } \\
\text { yellow stems in summer; very finely divided } \\
\text { blue-green leaves }\end{array}$ \\
\hline thermopsis & Thermopsis caroliniana & Thermopsis caroliniana & $\begin{array}{l}60 \text { inches high with spikes of sulphur-yellow pea } \\
\text { flowers in early summer }\end{array}$ \\
\hline speedwell & Veronica longifolia & $\begin{array}{l}\text { Veronica longifolia } \\
\text { 'Lavender Charm' }\end{array}$ & $\begin{array}{l}24-36 \text { inches high with violet-blue flowers in } \\
\text { erect dense spikes }\end{array}$ \\
\hline speedwell & Veronica spicata & $\begin{array}{l}\text { Veronica spicata } \\
\text { Blue Wonder' }\end{array}$ & 18 inches high with bright blue flowers \\
\hline violet & Viola & Viola & $\begin{array}{l}\text { 6-12 inches high with violet flowers in spring; } \\
\text { heart-shaped leaves }\end{array}$ \\
\hline
\end{tabular}

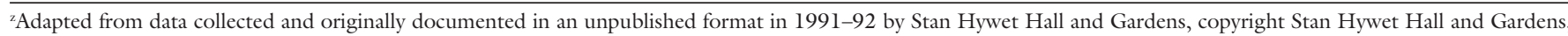
Akron, Ohio.

${ }^{\mathrm{y}} 1.0$ inch $=2.54 \mathrm{~cm}$. 
integrity is not altered and features are not lost. This is particularly important during the research and long-term treatment planning process. To be effective, the maintenance program must have a guiding philosophy, approach or strategy; an understanding of preservation maintenance techniques; and a system for documenting changes in the landscape (Birnbaum, 1994; Coffin and Bellavia, 1998). Development of a historic landscape maintenance plan is an effective tool for integrating preservation objectives into landscape maintenance operations, and for planning and documenting work. Guidelines for the treatment of cultural landscapes recommend that both management and maintenance of historic landscapes be considered because well-conceived management and maintenance activities can sustain character and integrity over an extended period of time (Birnbaum and Peters, 1996). Though the maintenance plan has not yet been accomplished for the English Garden at Stan Hywet Hall and Gardens, it is still needed to ensure that the integrity of the English Garden is not lost or diminished over time.

\section{Conclusions}

According to Birnbaum and Peters (1996), "A cultural landscape may be a significant resource as a rare survivor of the work of an important landscape architect, horticulturist, or designer." The English Garden, as one of only a few restored works of Ellen Biddle Shipman in the U.S. that is open to the public, represents a highly significant historic landscape preservation project that provides an excellent model for illustrating typical and recommended historic landscape preservation processes. Documentation of this garden's restoration and the horticultural aspects of this work, including the list of historic plants and their modern plant substitutes, provides valuable information for others seeking to restore historic gardens.
The field of historic landscape preservation in the U.S. is still relatively young, having emerged over the past 30 years. As a growing, interdisciplinary field, historic landscape preservation will provide numerous opportunities for collaboration in project and scholarly written work. Much of the project work conducted to preserve historic landscapes is relevant to the field of horticulture. Land preservation is being increasingly recognized as an urgent matter, worthy of national attention, and as such, it has historical, sociological and horticultural significance. Therefore, increased visibility and presence of discussions related to historic landscape preservation in the literature of mainstream horticultural science will broaden the current knowledge and serve to build a bridge of communication between horticulture and the varied interdisciplinary interests of historic landscape preservation. This, in turn, will lead to increasing opportunities for shared forums among horticulturists and those readers who have a lay interest in historic landscape preservation topics, thus bringing horticulture to an even wider audience in the future.

\section{Literature cited}

Birnbaum, C.A. 1994. Protecting cultural landscapes: Planning, treatment and management of historic landscapes. Preservation Brief 36. U.S. Dept. Interior, Natl. Park Serv. Cultural Resources, Preservation Assistance Div., Washington D.C.

Birnbaum, C.A. and H.L. Barrett. 2000. Making educated decisions 2. A landscape preservation bibliography. Dept. Interior, Natl. Park Serv., Historic Landscape Initiative, Washington, D.C.

Birnbaum, C.A. and C.C. Peters (eds.) 1996. The Secretary of the Interior's standards for the treatment of historic properties with guidelines for the treatment of cultural landscapes. U.S. Dept. Interior. Natl. Park Serv., Cultural Resource Stewardship and Partnerships, Heritage Preservation Serv., Historic Landscape Initiative, Washington, D.C.
Coffin, M. and R.M. Bellavia. 1998. Guide to developing a preservation maintenance plan for a historic landscape. Cultural Landscape Publ. No. 7, Olmsted Ctr. for Landscape Preservation, Natl. Park Serv., Boston.

Griswold, M. and E. Weller. 1991. The golden age of American gardens. Abrams, New York.

Historic American Buildings Survey. 2003. American memory. Library of Congr. Prints and Photographs Div., Washington, D.C. 9 Sept. 2003. <http://memory.loc. gov/cgi-bin/query/r?ammen/hh:@field( NUMBER+@band $(\mathrm{OH} 0106))>$.

Levinson, N. 1991. Reconstructed grandeur. Landscape Architecture 81(6):64 65 .

Linden-Ward, B. 1987. Stan Hywet Hall and Gardens: Warren Manning's design intent at an Akron estate is recalled through his skillful restoration. Landscape Architecture 77(4):66-71

McCormick, K. 1994. On a clear day Akron's Stan Hywet Hall and Gardens restores its American style landscape. Historic Preservation 46(4):68, 70-71, 99-100.

Neckar, L. 1989. Developing landscape architecture for the twentieth century: The career of Warren H. Manning. Landscape J. 8(2):78-91.

Page, R.R., C.A. Gilbert, and S.A. Dolan. 1998. A guide to cultural landscape reports: Contents, process, and techniques. U.S Dept. Interior, Natl. Park Serv., Cultural Resource Stewardship and Partnerships, Park Historic Structures and Cultural Landscapes Program, Washington, D.C.

Rogers, E.B. 2001. Landscape design: A cultural and architectural history. Abrams, New York.

Tankard, J.B. 1996. The gardens of Ellen Biddle Shipman. Sagapress, Sagaponack, N.Y. 